\title{
P450 Pharmacogenetics in Indigenous North American Populations
}

\author{
Lindsay M. Henderson ${ }^{1}$ (i) , Katrina G. Claw ${ }^{1}$, Erica L. Woodahl ${ }^{2}$ (D) , Renee F. Robinson ${ }^{3,4}$, \\ Bert B. Boyer ${ }^{5}$, Wylie Burke ${ }^{6}$ and Kenneth E. Thummel ${ }^{1, *}$ \\ 1 Departments of Pharmaceutics, University of Washington, Seattle, WA 98195, USA; \\ lmhender@uw.edu (L.M.H.); kclaw@uw.edu (K.G.C.) \\ 2 Department of Biomedical and Pharmaceutical Sciences, University of Montana, Missoula, MT 59812, USA; \\ erica.woodahl@umontana.edu \\ 3 Southcentral Foundation, Anchorage, AK 99508, USA; RRobinson@SouthcentralFoundation.com \\ 4 United States Public Health Service, Department of Human Services, Washington, DC 20201, USA \\ 5 Center for Alaska Native Health Research, University of Alaska Fairbanks, Fairbanks, AK 99775, USA; \\ bert.boyer@gmail.com \\ 6 Bioethics \& Humanities, University of Washington, Seattle, WA 98195, USA; wburke@uw.edu \\ * Correspondence: thummel@uw.edu
}

Received: 18 December 2017; Accepted: 22 January 2018; Published: 1 February 2018

\begin{abstract}
Indigenous North American populations, including American Indian and Alaska Native peoples in the United States, the First Nations, Métis and Inuit peoples in Canada and Amerindians in Mexico, are historically under-represented in biomedical research, including genomic research on drug disposition and response. Without adequate representation in pharmacogenetic studies establishing genotype-phenotype relationships, Indigenous populations may not benefit fully from new innovations in precision medicine testing to tailor and improve the safety and efficacy of drug treatment, resulting in health care disparities. The purpose of this review is to summarize and evaluate what is currently known about cytochrome $P 450$ genetic variation in Indigenous populations in North America and to highlight the importance of including these groups in future pharmacogenetic studies for implementation of personalized drug therapy.
\end{abstract}

Keywords: American Indian; Alaska Native; First Nations; Inuit; Mexican Amerindians; cytochrome P450; pharmacogenetics; allele frequency; drug metabolism

\section{Introduction}

Pharmacogenetics, a form of genomic medicine, aims to establish how genetic variation can affect an individual's response to drugs, guiding the selection of the best drug and dose for a patient to improve healthcare quality [1]. The field of pharmacogenetics has the potential to improve health outcomes and reduce the cost of care by maximizing therapeutic success and minimizing the risk of adverse drug reactions or therapeutic failure at the population and potentially the individual level. However, a major issue in the translation of pharmacogenetic research into clinical practice is that existing databases have been populated from studies that lack significant ethnic and racial diversity.

Although diversity in genomic research, including pharmacogenetics, has increased in recent years, oversampling of populations of European ancestry continues to be a problem in the field. Indeed, the latest analysis of genome-wide association studies found that $81 \%$ of samples were from individuals of European ancestry [2]. The non-European portion was comprised of mostly Asian ancestry, leaving just $5 \%$ for the rest of the world's populations [2]. Failure to include diverse populations in genomic studies leads to a biased understanding of the health implications of genetic variation and resulting medical findings may be preferentially beneficial to patients of European 
ancestry. Increased attention to genetic data from diverse populations is required to give "everyone the best chance at good health" [3]. This review article addresses the limited published pharmacogenetic research with Indigenous peoples of North America (Canada, United States and Mexico) and the challenges this poses for clinical practice.

According to the 2011 National Household Survey in Canada, 1.4 million people reported Canadian Aboriginal identity, representing a population increase of $20 \%$ since 2006 [4]. Of this population, $60.8 \%$ identified as First Nations (FN) people, $32.3 \%$ as Métis and $4.2 \%$ as Inuit. We will refer to the individuals described in previous studies as Canadian Aboriginal, Canadian Native Indian and Canadian Indigenous as FN, Métis, or Inuit peoples, or more broadly as "Indigenous peoples of Canada," in this review. The 2010 United States Census reported that 5.2 million American Indian and Alaska Native (AIAN) people live in the United States, with the AIAN population having grown 39\% in the preceding decade [5]. The population of Mexico is stratified into two main groups: Amerindians, Indigenous people with over 68 ethnic groups representing 7\% of the Mexican population and Mestizos, a group that arose as the result of admixture among Europeans, Amerindians and African slaves [6-8]. For the purposes of this paper, Amerindian will refer to Amerindian Indigenous populations from Mexico.

While much work has been conducted investigating the clinical importance of the cytochrome P450 (P450) gene variants, there is relatively little data specifically addressing P450 variation and its consequences in Indigenous populations [9]. Geographical isolation, unbalanced resource allocation, failure of researchers to include Indigenous communities in study design and reluctance to participate in studies due to historical and recent research misconduct all contribute to under-representation of Indigenous populations in biomedical (including genetic) research studies [2,10-14]. However, it is important to understand the unique genetic variation that arises in these historically isolated populations because there are clinical implications of having uncharacterized genetic variation, particularly with drug metabolizing enzymes.

The $P 450$ genes encode a group of highly polymorphic enzymes that play a critical role in drug metabolism [15]. There are 57 P450 genes in humans, with members of the CYP1, CYP2 and CYP3 families being responsible for most of the metabolic clearance of the approximately $75 \%$ of all drugs that are eliminated from blood by this process [16-18]. Variation in these $P 450$ genes can result in proteins with altered catalytic activity or abundance (referred to collectively hereafter as 'enzyme activity'), leading to high inter-individual variability in systemic drug elimination and pharmacological response [19]. Gene sequence changes (single nucleotide variation and structural variation referred to collectively as alleles) that lead to altered P450 enzyme activity can be classified into four phenotypic groups: poor metabolizer (PM), intermediate metabolizer (IM), extensive metabolizer (EM) and ultra-rapid metabolizer (UM). PMs are generally homozygous for a variant allele that causes a complete loss of enzyme activity (null allele), IMs can be heterozygous for a reference allele and a null allele or a combination of reduced function alleles, EMs have two reference activity alleles and UMs have multiple copies of the $P 450$ gene or a variant that increases total enzyme activity, relative to the reference enzyme. Enzyme activity is inversely related to systemic parent drug exposure, which drives most pharmacological effects.

Indigenous populations can have distinct variant allele frequencies, which are related to historic geographical isolation and arise due to genetic drift, selective pressures and the founder effect. The population-level differences in $P 450$ allele frequencies in Indigenous peoples requires consideration to avoid negative clinical outcomes including the potential for phenotypic misclassification and inappropriate drug utilization, further contributing to health care disparities. This review focuses on what is currently known about $P 450$ pharmacogenetics in Indigenous North American populations and how the unique variation found in these populations may impact drug metabolism and response. We have intentionally clustered these peoples by their shared heritage and geographical proximity, though we acknowledge that each group has their own unique histories, languages and cultural traditions. 


\section{Methods}

The primary focus of this review is to provide a summary of the $P 450$ pharmacogenetic research conducted with and for Indigenous North American populations. We conducted a systematic literature review to identify published studies of $P 450$ genetic variation, allele frequency and drug metabolism in AIAN, Indigenous peoples of Canada and Amerindians. A search of PubMed was performed using the keywords "Alaska Native," "American Indian," "Native American," Canadian Native Indian," "First Nations," "Canadian Inuit," "Mexico Amerindian," "Mexico Indigenous," "cytochrome P450 polymorphisms," "Pharmacogenetics," and "CYP450 allele frequencies," "drug disposition," and "drug metabolism." Inclusion criteria were original research studies published in English and cited in PubMed between 1990 and October 2017. Figure 1 depicts the number of records identified and included or excluded by the aforementioned criteria.

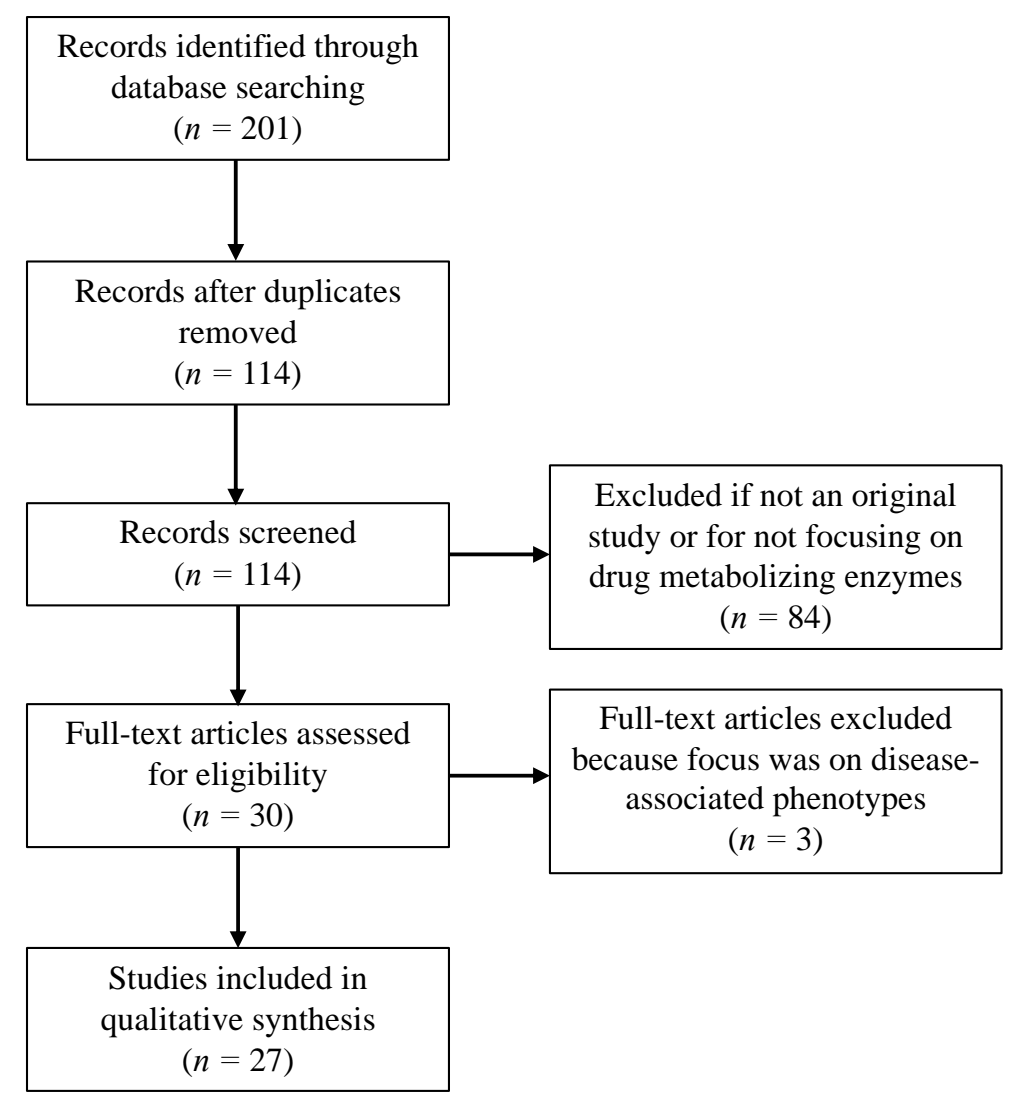

Figure 1. Flow diagram depicting the number of records identified, included and excluded in this review.

The following data were abstracted from selected studies: number of individuals in the study, the study population, P450 enzymes, method for genotyping and phenotyping, allele frequencies and conclusions from the study. For some of these studies, a reference population (e.g., European or Mestizos descent) was included. Our focus was to review available data for Indigenous North American populations, but we note that the studies reported in this review contain inconsistent approaches to population description for comparator populations, which may be categorized by race, ethnicity, nationality, or geographic location. Summary tables (Tables 2-13) also include reference data for different racial groups abstracted from the 1000 Genomes database (SNVs) [20] or from Zhou et al. [21] (complex haplotypes or structural variation not readily obtained from 1000 Genomes). 


\section{Results}

We identified twenty-seven studies that met our inclusion criteria. These studies reported $P 450$ polymorphisms in Indigenous North American populations for CYP1A1, CYP1A2, CYP2A6, CYP2B6, CYP2C9, CYP2C19, CYP2D6, CYP2E1, CYP3A4, CYP3A5 and CYP4F2. Six studies were in AIAN people, seven studies were in Indigenous people of Canada and fourteen studies were in Amerindian populations of Mexico. Figure 2 shows the geographical locations of the study populations and Table 1 summarizes the study results.

Table 1. Studies of $P 450$ genetic polymorphisms in Indigenous North American populations.

\begin{tabular}{|c|c|c|c|}
\hline Reference & Genes & $\begin{array}{c}\text { Population (Tribal Group } \\
\text { or Affiliation) }\end{array}$ & Genotyping/Phenotyping Method and Study Conclusion \\
\hline Fragoso, 2005 [22] & CYP1A1 & $\begin{array}{l}106 \text { Amerindian } \\
\text { (Teenek and Mayo) }\end{array}$ & $\begin{array}{l}\text { Genotype was determined by allele-specific PCR. The frequency of } \\
\text { CYP1A1 variants is distinct for Amerindian and Mestizo } \\
\text { populations of Mexico. }\end{array}$ \\
\hline de Andrés, 2017 [23] & $\begin{array}{l}\text { CYP1A2 } \\
\text { CYP2C9 } \\
\text { CYP2C19 } \\
\text { CYP2D6 } \\
\text { CYP3A4 }\end{array}$ & $\begin{array}{l}450 \text { Amerindian } \\
\text { (Tarahumara, Tepehuano, } \\
\text { Mexicanera, Huichol, Cora, } \\
\text { Seri, Mayo and Guarijío) }\end{array}$ & $\begin{array}{l}\text { Genotype was determined by RT-PCR and then compared to } \\
\text { phenotype, which was determined by a probe substrate cocktail } \\
\text { approach using caffeine for CYP1A2, losartan for CYP2C9, } \\
\text { omeprazole for } C Y P 2 C 19 \text {, followed by dextromethorphan for } \\
C Y P 2 D 6 \text { and CYP3A4. Further studies are needed to identify and } \\
\text { characterize rare variants in the Amerindian population to improve } \\
\text { genotype-phenotype predictions. }\end{array}$ \\
\hline Binnington, 2012 [24] & $\begin{array}{l}\text { CYP2A6 } \\
\text { CYP2B6 }\end{array}$ & 400 AN (Yup'ik) & $\begin{array}{l}\text { Genotype was determined by two-step allele-specific PCR. Study } \\
\text { found an association between nicotine metabolism and CYP2A6 } \\
\text { genotype. High CYP2A6 activity may contribute to the high risk of } \\
\text { tobacco-related diseases in the Yup'ik AN population. }\end{array}$ \\
\hline Tanner, 2017 [25] & CYP2A6 & $\begin{array}{l}636 \mathrm{AI} \text { (Northern Plains and } \\
\text { Southwest tribes) }\end{array}$ & $\begin{array}{l}\text { Genotype was determined by two-step allele-specific PCR and } \\
\text { RT-PCR. The Northern Plains and Southwest AI populations have } \\
\text { unique profiles of CYP2A6 genetic variation that contributes to } \\
\text { differences in nicotine metabolism and tobacco-related disease risks. }\end{array}$ \\
\hline Nowak, 1998 [26] & $\begin{array}{l}\text { CYP2A6 } \\
\text { CYP2C19 }\end{array}$ & $159 \mathrm{FN}$ & $\begin{array}{l}\text { Genotype was determined by PCR-RFLP. FN people have distinct } \\
\text { frequencies of variant alleles in CYP2A6 and CYP2C19 compared to } \\
\text { European and Asian populations. }\end{array}$ \\
\hline Schoedel, 2004 [27] & CYP2A6 & $101 \mathrm{FN}$ & $\begin{array}{l}\text { Genotype was determined by two-step allele-specific PCR. CYP2A6 } \\
\text { allele frequencies were markedly different between FN and other } \\
\text { ethnic groups, suggesting differences in nicotine metabolism. }\end{array}$ \\
\hline Gaedigk, 2001 [28] & CYP2C9 & 153 FN 151 Inuit & $\begin{array}{l}\text { Genotype was determined by PCR-RFLP. The CYP2C9 allele } \\
\text { frequencies in the FN and Inuit populations differ from the } \\
\text { European and Asian reference populations, likely as a result of } \\
\text { genetic drift and selective pressures }\end{array}$ \\
\hline Dorado, 2011 [29] & CYP2C9 & 99 Amerindian (Tepehuano) & $\begin{array}{l}\text { Genotype was determined by RT-PCR. CYP2C9 variation in } \\
\text { Tepehuanos and Mestizos was found to be distinct compared to that } \\
\text { reported in Mexican Americans and Spaniards }\end{array}$ \\
\hline $\begin{array}{l}\text { Sosa-Macías, } \\
2013 \text { [30] }\end{array}$ & CYP2C9 & $\begin{array}{c}505 \text { Amerindian } \\
\text { (Tepehuano, Mexicanera, } \\
\text { Huichol, Seri, Guarijío, } \\
\text { Mayo, Cora } \\
\text { and Tarahumara) }\end{array}$ & $\begin{array}{l}\text { Genotype was determined by RT-PCR. The allele frequencies for } \\
\text { CYP2C } 9 \text { variants that confer PM phenotype were determined in } \\
\text { eight Amerindian groups of Northwest Mexico. }\end{array}$ \\
\hline $\begin{array}{l}\text { Castelán-Martínez, } \\
2013 \text { [31] }\end{array}$ & CYP2C9 & $\begin{array}{l}\text { 483 Amerindian } \\
\text { (Nahua, Teenek, } \\
\text { Tarahumara, Purepecha } \\
\text { and Huichol) }\end{array}$ & $\begin{array}{l}\text { Genotype was determined by RT-PCR. Two PM conferring CYP2C9 } \\
\text { variants were investigated in five Amerindian populations and } \\
\text { compared to other reports of CYP2C9 variation in } \\
\text { Amerindians and Mestizos. }\end{array}$ \\
\hline Fohner, 2013 [32] & $\begin{array}{l}\text { CYP2C9 } \\
\text { CYP2D6 } \\
\text { CYP3A4 } \\
\text { CYP3A5 }\end{array}$ & $\begin{array}{l}\text { 94-187 AI (Salish, Pend } \\
\text { d'Oreille and Kootenai) }\end{array}$ & $\begin{array}{l}\text { CYP2D6 was completely resequenced, while exons, adjacent introns } \\
\text { and flanking regions were resequenced for CYP3A4, CYP3A5 and } \\
\text { CYP2C9. Sanger sequencing was used for resequencing and } \\
\text { CYP2D6 copy number was determined by PCR. Findings from } \\
\text { pharmacogenetic studies conducted in European populations do not } \\
\text { necessarily apply to AIAN populations. Particularly with CYP3A4 } \\
\text { allele frequency, the Confederated Salish and Kootenai Tribes have } \\
\text { unique allelic variation distinct from European Americans. }\end{array}$ \\
\hline Fohner, 2015 [33] & $\begin{array}{l}\text { CYP2C9 } \\
\text { CYP4F2 }\end{array}$ & $\begin{array}{l}380 \text { AIAN (multiple AN } \\
\text { sub-cultures and aggregate } \\
\text { of AI tribes) } 350 \text { AN (Yup'ik) }\end{array}$ & $\begin{array}{l}\text { Allele frequencies of novel and previously known variants in } \\
\text { warfarin pharmacogenes were determined by Sanger resequencing, } \\
\text { followed by targeting genotyping, using the Fluidigm platform, } \\
\text { in AN and AI populations. }\end{array}$ \\
\hline $\begin{array}{c}\text { McGrane and } \\
\text { Loveland, 2016 [34] }\end{array}$ & $\begin{array}{l}\text { CYP2C9 } \\
\text { CYP2C19 } \\
\text { CYP2D6 }\end{array}$ & 123 AI (Northwest) & $\begin{array}{l}\text { Genotype was determined by qPCR. Study identified differences in } \\
\text { genetic polymorphism frequencies in AI and European American } \\
\text { youth in the US Northwest. }\end{array}$ \\
\hline
\end{tabular}


Table 1. Cont.

\begin{tabular}{|c|c|c|c|}
\hline $\begin{array}{c}\text { Jurima-Romet, } \\
1996 \text { [35] }\end{array}$ & CYP2C19 & 155 Inuit & $\begin{array}{l}\text { Genotype results for } C Y P 2 C 19 \text {, determined by allele-specific PCR, } \\
\text { were found to be concordant with phenotype results, using R/S } \\
\text { mephenytoin enantiomeric ratio. The CYP2C19 PM variant allele } \\
\text { frequencies in the Inuit population appear to be more similar to the } \\
\text { European, rather than Asian, population. }\end{array}$ \\
\hline Oestreich 2014, [36] & CYP2C19 & 100 AI (Sioux) & $\begin{array}{l}\text { Genotype was determined by RT-PCR. The prevalence of } C Y P 2 C 19 \\
\text { PM conferring variants was determined to be lower or similar to } \\
\text { Europeans. No significant association was observed between } \\
\text { genotype and a marker for clopidogrel effectiveness. }\end{array}$ \\
\hline $\begin{array}{l}\text { Salazar-Flores, } \\
\quad 2012[37]\end{array}$ & $\begin{array}{l}\text { CYP2C19 } \\
\text { CYP2D } 6\end{array}$ & $\begin{array}{l}365 \text { Amerindian } \\
\text { (Tarahumara, Purepecha, } \\
\text { Tojolabal, Tzotzil } \\
\text { and Tzeltal) }\end{array}$ & $\begin{array}{l}\text { Genotype was determined by SNapShot multiplex PCR. With the } \\
\text { exception of the Tarahumaras, the frequency of CYP2C19 variants } \\
\text { that confer PM phenotype was low. The frequency of CYP2D6 PMs } \\
\text { is also expected to be low in these Amerindian populations. }\end{array}$ \\
\hline $\begin{array}{l}\text { Jurima-Romet, } \\
1997[38]\end{array}$ & CYP2D6 & 155 Inuit & $\begin{array}{l}\text { Genotype was determined by PCR-RFLP and dextromethorphan } \\
\text { was used as a probe for CYP2D6 phenotype. Genotype results for } \\
\text { CYP2D } 6 \text { were found to be concordant with phenotype results. } \\
\text { The Inuit population had unique CYP2D6 variation, distinct from } \\
\text { European or Asian populations. }\end{array}$ \\
\hline Nowak, 1997 [39] & CYP2D 6 & $156 \mathrm{FN}$ & $\begin{array}{l}\text { Genotype was determined by mutation-specific PCR and } \\
\text { dextromethorphan was used as a probe for CYP } 2 \text { D } 6 \text { phenotype. } \\
\text { The FN population had a low frequency of CYP2D } 6 \text { variants that } \\
\text { result in decreased metabolic activity, compared to European and } \\
\text { Asian populations. }\end{array}$ \\
\hline $\begin{array}{l}\text { Lares-Asseff, } \\
2005[40]\end{array}$ & CYP2D 6 & 55 Amerindian (Tepehuano) & $\begin{array}{l}\text { All Tepehuanos included in this study were found to be CYP2D6 } \\
\text { EMs by phenotyping with dextromethorphan. }\end{array}$ \\
\hline $\begin{array}{l}\text { Sosa-Macías, } \\
2006[41]\end{array}$ & CYP2D 6 & $\begin{array}{l}101 \text { Amerindian } \\
\text { (Tepehuano) }\end{array}$ & $\begin{array}{l}\text { Genotype was determined by PCR-RFLP and dextromethorphan } \\
\text { was used as a probe for CYP2D6 phenotype. The distribution of } \\
\text { CYP2D6 variant alleles was markedly different between Tepehuano } \\
\text { Amerindians and Mestizos; no Tepehuanos were classified as } \\
\text { CYP2D6 PMs. }\end{array}$ \\
\hline $\begin{array}{l}\text { Sosa-Macías, } \\
2010 \text { [42] }\end{array}$ & CYP2D 6 & 99 Amerindian (Tepehuano) & $\begin{array}{l}\text { This study expanded upon Sosa-Macías et al. } 2006 \text { by genotyping } \\
\text { for additional CYP2D6 variants, which had different frequencies } \\
\text { than that observed in Mestizos. RT-PCR and XL-PCR were used to } \\
\text { determine genotype. }\end{array}$ \\
\hline $\begin{array}{l}\text { Lazalde-Ramos, } \\
\quad 2014 \text { [43] }\end{array}$ & CYP2D 6 & $\begin{array}{l}508 \text { Amerindian } \\
\text { (Tarahumara, Tepehuano, } \\
\text { Huichol, Mexicanera, Cora, } \\
\text { Seri, Guarijío and Mayo) }\end{array}$ & $\begin{array}{l}\text { Genotype was determined by XL-PCR and copy number was } \\
\text { evaluated by RT-PCR. The Amerindian populations included in this } \\
\text { study had a lower frequency of CYP2D6 PM conferring variants but } \\
\text { a higher frequency of gene duplication conferring UM phenotype, } \\
\text { compared to the Mestizo population. }\end{array}$ \\
\hline $\begin{array}{l}\text { López-López, } \\
2014 \text { [44] }\end{array}$ & CYP2D6 & $\begin{array}{l}154 \text { Amerindian } \\
\text { (Mayan Lacandon) }\end{array}$ & $\begin{array}{l}\text { Genotype was determined by XL-PCR. The Amerindian population } \\
\text { had a low frequency of CYP2D } 6 \text { low or null activity alleles, } \\
\text { compared to Mestizos. The frequency UM genotypes, } \\
\text { determined by PCR-RFLP, were similar between Mayan } \\
\text { Lacandones and Mestizos. }\end{array}$ \\
\hline $\begin{array}{l}\text { Perez-Paramo, } \\
\quad 2015[45]\end{array}$ & CYP2D6 & $\begin{array}{l}110 \text { Amerindian } \\
\text { (Tzotzil and Tzeltal) }\end{array}$ & $\begin{array}{l}\text { Genotype was determined by XL-PCR. The CYP2D6 alleles that } \\
\text { confer low or null activity, as well as the gene duplication that } \\
\text { confers UM phenotype, had lower frequencies in the Amerindian } \\
\text { population compared to the Mestizo population. }\end{array}$ \\
\hline Howard, 2003 [46] & CYP2E1 & $114 \mathrm{FN}$ & $\begin{array}{l}\text { PCR based genotyping and size discrimination by agarose gel were } \\
\text { used to determine genotype. Compared to Canadian Europeans, } \\
\text { the FN population had a significantly higher frequency of a CYP2E1 } \\
\text { variant associated with greater enzyme induction. }\end{array}$ \\
\hline $\begin{array}{l}\text { Gordillo-Bastidas, } \\
\quad 2010 \text { [47] }\end{array}$ & CYP2E1 & 101 Amerindian (Huichol) & $\begin{array}{l}\text { Genotype was determined by PCR-RFLP. Compared to other world } \\
\text { populations, the Huichol population had a high frequency of } \\
\text { a CYP2E1 variant associated with higher enzyme activity. }\end{array}$ \\
\hline $\begin{array}{l}\text { Reyes-Hernández, } \\
2008 \text { [48] }\end{array}$ & СYР3A4 & $\begin{array}{l}100 \text { Amerindian } \\
\text { (Tepehuano) }\end{array}$ & $\begin{array}{l}\text { Genotype was determined by PCR-RFLP. CYP3A4 variation was not } \\
\text { significantly different between the Tepehuano and } \\
\text { Mestizo populations. }\end{array}$ \\
\hline
\end{tabular}

PCR: Polymerase Chain Reaction; RT-PCR: real-time PCR; AN: Alaska Native; FN: First Nations; RFLP: restriction fragment length polymorphism; qPCR: quantitative Polymerase Chain Reaction; AI: American Indian; PM: poor metabolizer; UM: ultra-rapid metabolizer; XL-PCR: EXtra Long Polymerase Chain Reaction. 


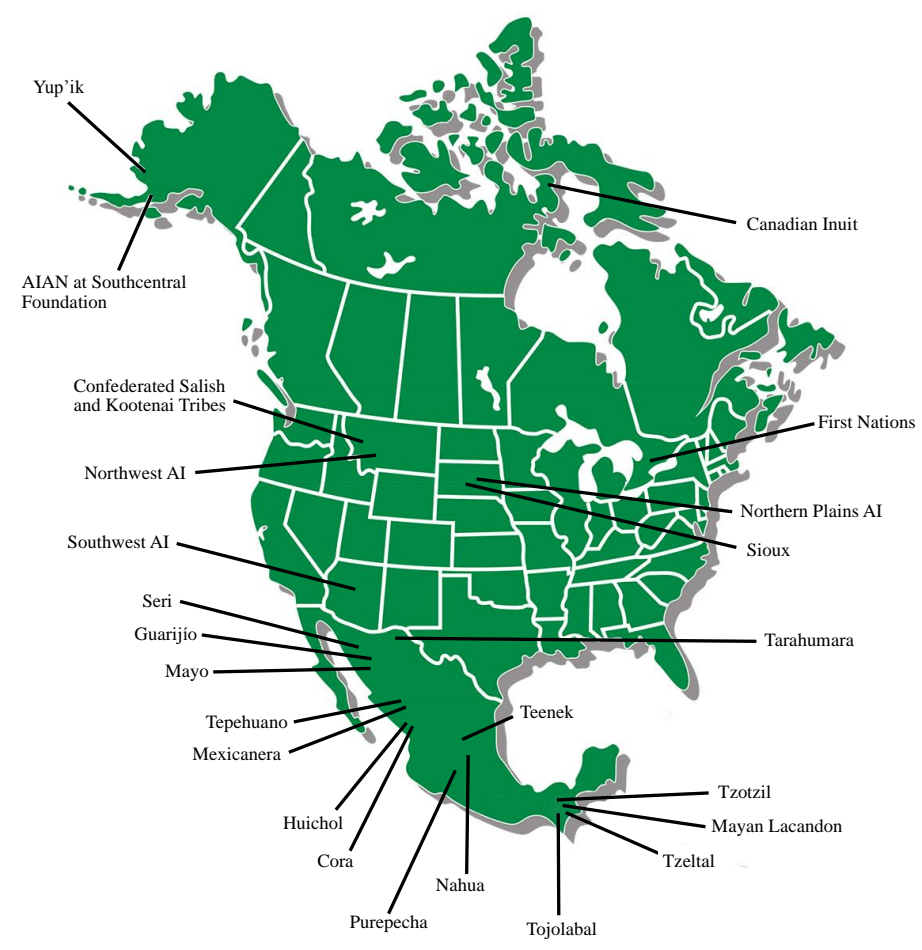

Figure 2. Map of North America with general locations of Indigenous populations included in this review.

\subsection{CYP1A1}

The CYP1A1 enzyme plays a role in the metabolism of caffeine [49] as well as the bioactivation of polycyclic aromatic hydrocarbons [50]. The $C Y P 1 A 1^{*} 2 A$ variant located in the $3^{\prime}$ non-coding region confers a restriction endonuclease site for cleavage by $M s p 1$ (Figure 3) [51]. CYP1A1*2C is characterized by a nonsynonymous base change that results in an amino acid substitution associated with an increase in CYP1A1 gene inducibility (Figure 3) [52,53].

The frequencies of $C Y P 1 A 1^{*} 2 A$ and ${ }^{*} 2 C$ were determined in two Amerindian peoples, the Teenek and Mayos and compared to the Mestizo Mexican population [22]. In the Teenek population, the minor allele frequencies (MAFs) of $C Y P 1 A 1 * 2 A$ and ${ }^{*} 2 C$ were 71.4 and $65.4 \%$, respectively and in the Mayos the MAFs were 46.9 and $54.6 \%$, respectively (Table 2) [22]. Both Amerindian populations had a significantly higher frequency of $C Y P 1 A 1^{*} 2 C$ compared to the Mexican Mestizo population $(34.4 \%)$, while only the Teenek had a significantly higher frequency of $C Y P 1 A 1^{*} 2 A$ compared to the Mestizo population (40.1\%) [22].

Table 2. Comparison of CYP1A1 allele frequencies in Indigenous North American populations to global populations from the 1000 Genomes Project [20]. N represents the number of alleles. Global populations are abbreviated as follows: African Ancestry in Southwest US (ASW); Utah residents with Northern and Western European ancestry (CEU); Han Chinese in Beijing, China (CHB); Mexican Ancestry in Los Angeles, California (MXL).

\begin{tabular}{cccccc}
\hline \multirow{2}{*}{ Country } & \multirow{2}{*}{ Population } & \multirow{2}{*}{$N$} & \multicolumn{2}{c}{ CYP1A1 MAF (\%) } & \multirow{2}{*}{ Refs. } \\
\cline { 4 - 5 } & & & $* 2 A$ rs4646903 & $*$ 2C rs1048943 & \\
\hline \multirow{2}{*}{ Mexico } & Mayo & 108 & 46.9 & 54.6 & {$[22]$} \\
& Teenek & 104 & 71.4 & 65.4 & {$[22]$} \\
\hline \multirow{2}{*}{ Multiple } & MXL & 128 & 39.8 & 33.6 & {$[20]$} \\
Countries & CHB & 206 & 43.7 & 26.7 & {$[20]$} \\
$(1000$ Genomes $)$ & CEU & 198 & 9.1 & 4.0 & {$[20]$} \\
& ASW & 122 & 27.1 & 5.7 & {$[20]$} \\
\hline \multicolumn{7}{c}{ MAF: minor allele frequency. }
\end{tabular}

MAF: minor allele frequency. 


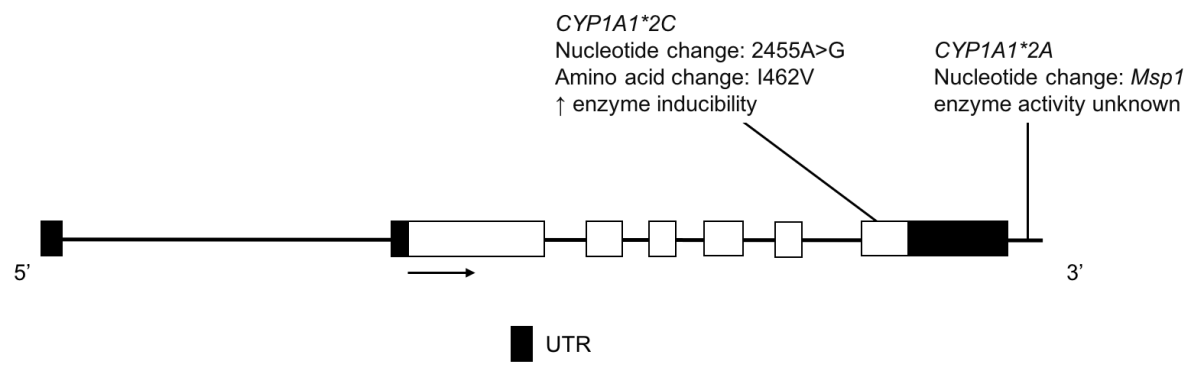

Figure 3. The human CYP1A1 gene and variants detected in two Amerindian populations. Exon 1 is untranslated in CYP1A1. Open boxes represent exons, lines represent introns and shaded boxes represent untranslated region (UTR).

\section{2. $C Y P 1 A 2$}

CYP1A2 is a highly polymorphic enzyme responsible for the metabolism of many drugs including clozapine [54], mirtazapine [55], theophylline [56], tizanidine [57] and triamterene [58]. CYP1A2*1F is associated with increased enzyme activity in the presence of an inducer, such as high caffeine consumption or heavy cigarette use (Figure 4) [59-61].

De Andrés et al. found that the CYP1A2*1F allele was present at a MAF of $66.6 \%$ in the Amerindian population (Tarahumara, Tepehuano, Mexicanera, Huichol, Cora, Seri, Mayo and Guarijío) (Table 3) [23]. Using $100 \mathrm{mg}$ of caffeine, as part of a probe drug cocktail for phenotyping, no association between $C Y P 1 A 2^{*} 1 F$ and higher enzyme activity was observed [23]. However, the $C Y P 1 A 2^{*} 1 F$ variant does not confer high constitutive activity but rather increases enzyme inducibility with exposure to an inducer, so the lack of genotype-phenotype association could be due to the fact that subjects were not stratified by their level of intake of a CYP1A2 inducer, such as high dose caffeine.

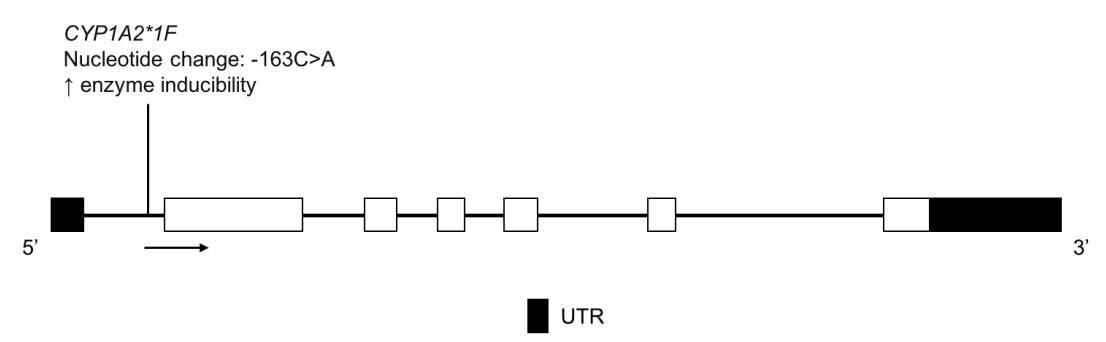

Figure 4. The human $C Y P 1 A 2$ gene and the $C Y P 1 A 2 * 1 F$ variant detected in the Amerindian population. Exon 1 is untranslated in CYP1A2. Open boxes represent exons, lines represent introns and shaded boxes represent UTR.

Table 3. Comparison of CYP1A2 allele frequencies in Indigenous North American populations to global populations from the 1000 Genomes Project [20]. $N$ represents the number of alleles. Global populations are abbreviated as follows: African Ancestry in Southwest US (ASW); Utah residents with Northern and Western European ancestry (CEU); Han Chinese in Beijing, China (CHB); Mexican Ancestry in Los Angeles, California (MXL).

\begin{tabular}{|c|c|c|c|c|}
\hline \multirow{2}{*}{ Country } & \multirow{2}{*}{ Population } & \multirow{2}{*}{$N$} & CYP1A2*1F MAF (\%) & \multirow{2}{*}{ Refs. } \\
\hline & & & rs762551 & \\
\hline Mexico & $\begin{array}{l}\text { Aggregate of Amerindian tribes } \\
\text { (Tarahumara, Tepehuano, } \\
\text { Mexicanera, Huichol, Cora, Seri, } \\
\text { Mayo and Guarijío) }\end{array}$ & 896 & 66.6 & [23] \\
\hline \multirow{4}{*}{$\begin{array}{l}\text { Multiple Countries } \\
\text { (1000 Genomes) }\end{array}$} & MXL & 128 & 73.4 & [20] \\
\hline & $\mathrm{CHB}$ & 206 & 63.6 & [20] \\
\hline & CEU & 198 & 72.7 & [20] \\
\hline & ASW & 122 & 63.9 & [20] \\
\hline
\end{tabular}




\section{3. $C Y P 2 A 6$}

The CYP2A6 enzyme metabolizes some clinically used drugs as well as several pro-carcinogenic compounds. Its substrates include nicotine [62], tegafur [63], valproic acid [64,65], as well as the activity probe coumarin [66] and tobacco-related nitrosamines such as NNK [4-(methyl-nitrosamino)-1-(3-pyridyl)-1-butanone] [67] and NNN ( $N$-nitrosonornicotine) [68]. Nicotine is one of the best studied CYP2A6 substrates. Renal clearance of nicotine is low and most of its metabolism (principally to cotinine) is catalyzed by CYP2A6; thus, associations between genetic variations in CYP2A6 and nicotine metabolic clearance are strong [62,69]. In addition, CYP2A6 is the main enzyme responsible for converting cotinine to trans-3'-hydrocotinine [70-72]. This observation has led to use of the trans-3'-hydrocotinine/cotinine ratio (NMR) as a quantitative measure of CYP2A6 activity and nicotine exposure in cigarette smokers [73]. The decreased activity or loss of function variants, CYP2A6*2,*4*5,*7,*9,*10,*12,*17 and *35 and several others, all reduce the rate of nicotine metabolism, compared to the reference allele (Figure 5) [69,73]. Moreover, CYP2A6 genotype and the NMR have been associated with the efficacy of nicotine replacement therapy [74-76] and, following the success of a recent randomized clinical trial [77], have been proposed as biomarkers to guide drug selection for smoking cessation pharmacotherapy [78].

In the Yup'ik AN population, the MAFs for $C Y P 2 A 6 * 2, * 4,{ }^{*},{ }^{*} 10$ and ${ }^{*} 12$ were found to be 0.4 , $14.5,8.9,1.9$ and $0.4 \%$, respectively (Table 4) [24]. In the FN population, the MAFs for CYP2A6*4, ${ }^{*} 9$ and ${ }^{*} 12$ were $1.0,15.5$ and $0.5 \%$, respectively and while CYP2A ${ }^{*} 2$ was not detected in this study, it was reported at a low MAF of $0.9 \%$ in a FN population by Nowak et al. (Table 4) [26,27]. These data highlight the very substantial differences in MAFs for a given P450 gene across indigenous populations.

Tanner et al. compared variation in CYP2A6 and NMR in two different AI populations and assessed differences in relation to smoking behaviors and risks [25]. In Northern Plains (NP) AIs, the CYP2A6*2, ${ }^{*} 4{ }^{*} 9$ and ${ }^{*} 12$, the MAFs were $0.3 \%, 1.6 \%, 11.9 \%$ and $0.3 \%$, respectively, while in AIs from the Southwest (SW) in Arizona the frequencies were 0.6, 0.3, 20.9 and 0.3\%, respectively (Table 4) [25]. CYP2A $6^{*} 7$ and ${ }^{*} 17$ were absent from the Yup'ik, NP and SW populations. While CYP2A6*35 was not found in the Yup'ik or NP, it had a MAF of $0.3 \%$ in the SW AI population (Table 4). The NP AI population had a lower frequency of $C Y P 2 A 6$ decreased function alleles and a higher rate of nicotine metabolism, compared to SW smokers [25]. CYP2A6 genetic variants are important to consider clinically because there are negative outcomes associated with higher rates of nicotine metabolism, including increased tobacco consumption, more difficulty with smoking cessation, poorer success with nicotine replacement therapy and elevated risk of lung cancer $[27,75,79]$.

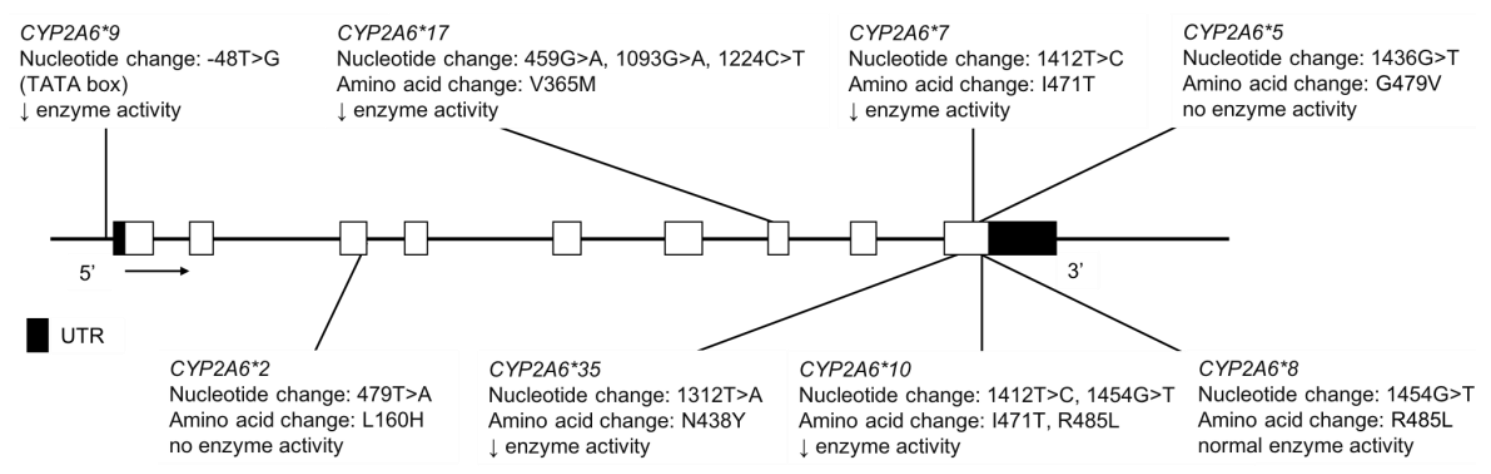

Figure 5. The human $C Y P 2 A 6$ gene and variants tested for in $\mathrm{AI}, \mathrm{AN}$ and FN populations. Not shown are $C Y P 2 A 6^{*} 4$, a full gene deletion and $C Y P 2 A 6^{*} 12$, an unequal crossover event where exons $1-2$ are from $C Y P 2 A 7$ and exons 3-9 from $C Y P 2 A 6$ are merged. Open boxes represent exons, lines represent introns and shaded boxes represent UTR. 
Table 4. Comparison of CYP2A6 allele frequencies in Indigenous North American populations to global populations from the 1000 Genomes Project [20]. N represents the number of alleles. Global populations are abbreviated as follows: African Ancestry in Southwest US (ASW); Utah residents with Northern and Western European ancestry (CEU); Han Chinese in Beijing, China (CHB); Mexican Ancestry in Los Angeles, California (MXL). For alleles not captured by 1000 Genomes (noted by $\ddagger$ ), the frequencies were extracted from Exome Aggregation Consortium [80] and for alleles defined by multiple variants, the frequencies reported in Zhou et al. [21] using LDLink software [81] were used. Global population data for CYP2A6*35 was not included because it is currently difficult to accurately genotype due to the high homology to $C Y P 2 A 7$, which can result in false positives and false negatives.

\begin{tabular}{|c|c|c|c|c|c|c|c|c|c|c|c|c|c|}
\hline \multirow{2}{*}{ Country } & \multirow{2}{*}{ Population } & \multirow{2}{*}{$N$} & \multicolumn{10}{|c|}{ CYP2A6 MAF (\%) } & \multirow{2}{*}{ Refs. } \\
\hline & & & $\begin{array}{c}* 2 \\
\text { rs1801272 }\end{array}$ & $* 4$ & $\begin{array}{c}* 5 \\
\text { rs5031017 }\end{array}$ & $\begin{array}{c}* 7 \\
\text { rs5031016 }\end{array}$ & $\begin{array}{c}* 8 \\
\text { rs28399468 }\end{array}$ & $\begin{array}{c}* 9 \\
\text { rs28399433 }\end{array}$ & $\begin{array}{c}{ }^{*} 10 \\
\text { rs5031016, } \\
\text { rs28399468 }\end{array}$ & ${ }^{*} 12$ & $\begin{array}{c}{ }^{*} 17 \\
\text { rs28399454 }\end{array}$ & $\begin{array}{c}* 35 \\
\text { rs143731390 }\end{array}$ & \\
\hline \multirow[b]{2}{*}{ Canada } & FN & 432 & 0.9 & - & - & - & - & - & - & - & - & - & [26] \\
\hline & FN & 202 & 0.0 & 1.0 & 0.5 & 0.0 & 0.0 & 15.5 & 0.0 & 0.5 & - & - & [27] \\
\hline \multirow[b]{2}{*}{ USA } & Yup'ik & 722 & 0.4 & 14.5 & - & 0.0 & 0.0 & 8.9 & 1.9 & 0.4 & 0.0 & 0.0 & {$[24]$} \\
\hline & NP AI & 636 & 0.3 & 1.6 & - & 0.0 & - & 11.9 & - & 0.3 & 0.0 & 0.0 & [25] \\
\hline \multirow{3}{*}{$\begin{array}{c}\text { Multiple } \\
\text { Countries } \\
(1000 \\
\text { Genomes })\end{array}$} & $\begin{array}{c}\text { MXL } \\
\text { Latino } \ddagger\end{array}$ & $\begin{array}{c}128 \\
11,576 \ddagger\end{array}$ & 1.6 & - & $<0.1 \ddagger$ & $0.3 \ddagger$ & - & 10.2 & - & - & 0.0 & - & $\begin{array}{c}{[20]} \\
{[80] \ddagger}\end{array}$ \\
\hline & $\begin{array}{c}\text { CHB } \\
\text { East Asian } \\
\ddagger\end{array}$ & $\begin{array}{c}206 \\
8528 \ddagger\end{array}$ & 0.0 & $17 \ddagger$ & $0.1 \ddagger$ & $12.9 \ddagger$ & $0.3 \ddagger$ & 26.7 & $0.3 \ddagger$ & - & 0.0 & - & $\begin{array}{c}{[20]} \\
{[21,80] \ddagger}\end{array}$ \\
\hline & $\begin{array}{c}\text { CEU } \\
\text { European }\end{array}$ & $\begin{array}{c}198 \\
66,714 \ddagger\end{array}$ & 3.5 & $1.0 \ddagger$ & $<0.1 \ddagger$ & $0.2 \ddagger$ & $0.3 \ddagger$ & 5.1 & $<0.1 \ddagger$ & - & 0.0 & - & $\begin{array}{c}{[20]} \\
{[21,80]}\end{array}$ \\
\hline
\end{tabular}




\section{4. $C Y P 2 B 6$}

The CYP2B6 enzyme metabolizes bupropion [82,83], cyclophosphamide [84], efavirenz [85], ketamine [86,87], methadone [88], as well as other drugs. It is also thought to contribute to nicotine metabolism when CYP2A6 activity is low [89]. CYP2B6*4 (K262R) variation confers increased enzyme activity, while $C Y P 2 B 6^{*} 6$ is a haplotype that includes both $\mathrm{K} 262 \mathrm{R}$ and $\mathrm{Q} 172 \mathrm{H}$ and confers reduced function (Figure 6); it is common among different ethnic groups. For example, in the Yup'ik AN population, the reported $C Y P 2 B 6^{*} 6$, was $51.7 \%$ (Table 5) [24]. Unlike CYP2A6, CYP2B6 genotype was not found to be associated with nicotine metabolism in this population. Previous studies found weak linkage disequilibrium between the CYP2A6 and CYP2B6 genes (localized together on chromosome 19), however, Binnington et al. reported strong linkage disequilibrium between these two genes in the Yup'ik population [24,90-92]. The authors proposed that the unique linkage disequilibrium observed between the reference $C Y P 2 A 6^{*} 1 B$ allele and the low activity $C Y P 2 B 6^{*} 6$ allele may be responsible for the higher nicotine metabolism in Yup'ik individuals with CYP2B6*6 genotype.

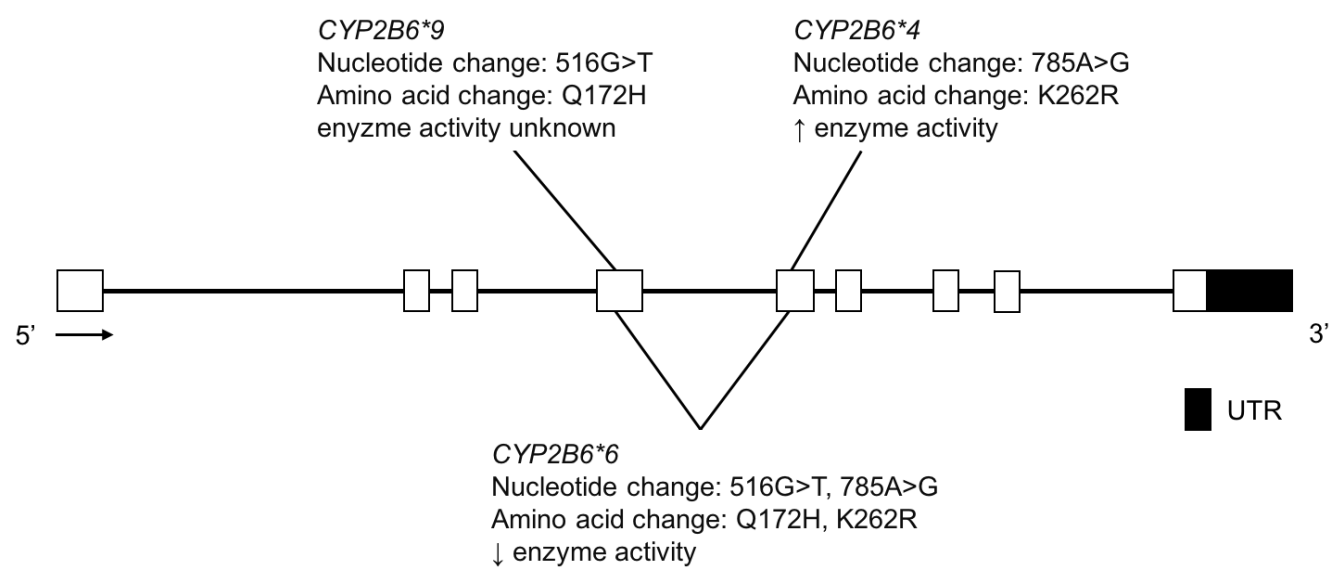

Figure 6. The human CYP2B6 gene and variants tested for in the Yup'ik AN population. Open boxes represent exons, lines represent introns and shaded boxes represent UTR.

Table 5. Comparison of CYP2B6 allele frequencies in an Indigenous North American population to global populations from the 1000 Genomes Project [20]. $N$ represents the number of alleles. Global populations are abbreviated as follows: African Ancestry in Southwest US (ASW); Utah residents with Northern and Western European ancestry (CEU); Han Chinese in Beijing, China (CHB); Mexican Ancestry in Los Angeles, California (MXL). For alleles not captured by 1000 Genomes (noted by $\ddagger$ ), the frequencies were extracted from Exome Aggregation Consortium [80] and for alleles defined by multiple variants, the frequencies reported in Zhou et al. [21] using LDLink software [81] were used.

\begin{tabular}{|c|c|c|c|c|c|c|}
\hline \multirow[b]{2}{*}{ Country } & \multirow[b]{2}{*}{ Population } & \multirow[b]{2}{*}{$N$} & \multicolumn{3}{|c|}{ CYP2B6 MAF (\%) } & \multirow[b]{2}{*}{ Refs. } \\
\hline & & & $\begin{array}{c}* 4 \\
\text { rs2279343 }\end{array}$ & $\begin{array}{c}* 6 \\
\text { rs2279343, } \\
\text { rs3745274 }\end{array}$ & $\begin{array}{c}* 9 \\
\text { rs3745274 }\end{array}$ & \\
\hline USA & Yup'ik & 722 & 0.0 & 51.7 & 0.0 & {$[24]$} \\
\hline \multirow{4}{*}{$\begin{array}{c}\text { Multiple } \\
\text { Countries } \\
(1000 \\
\text { Genomes })\end{array}$} & $\begin{array}{c}\text { MXL } \\
\text { Latino }\end{array}$ & $\begin{array}{c}128 \\
10,418\end{array}$ & $3.4^{\ddagger}$ & - & 31.3 & $\begin{array}{c}{[20]} \\
{[80]^{\ddagger}}\end{array}$ \\
\hline & $\begin{array}{c}\text { CHB } \\
\text { East Asian } \ddagger\end{array}$ & $\begin{array}{c}206 \\
8064^{\ddagger}\end{array}$ & $3.0 \ddagger$ & $2.7 \ddagger$ & 16.0 & $\begin{array}{c}{[20]} \\
{[21,80]}\end{array}$ \\
\hline & $\begin{array}{c}\text { CEU } \\
\text { European }\end{array}$ & $\begin{array}{c}198 \\
61,428\end{array}$ & $3.7 \ddagger$ & $3.4^{\ddagger}$ & 27.8 & $\begin{array}{c}{[20]} \\
{[21,80]}\end{array}$ \\
\hline & $\begin{array}{c}\text { ASW } \\
\text { African } \ddagger\end{array}$ & $\begin{array}{c}122 \\
8646^{\ddagger}\end{array}$ & $6.5 \ddagger$ & $5.8 \ddagger$ & 35.3 & $\begin{array}{c}{[20]} \\
{[21,80]}\end{array}$ \\
\hline
\end{tabular}




\subsection{CYP2C9}

The CYP2C9 enzyme metabolizes medications across many therapeutic classes [93] including nonsteroidal anti-inflammatories (e.g., naproxen) [94-97], angiotensin II blockers (e.g., losartan) [98], as well as narrow therapeutic index drugs such as (S)-warfarin [94,99], tolbutamide [100] and phenytoin [101]. Warfarin dosing is challenging and regularly monitored due to its wide inter-individual variability and narrow therapeutic index, which affects both its pharmacokinetics and pharmacodynamic response. AN populations are reported to require a lower dose of warfarin to achieve a desired therapeutic effect, with the average daily dose for the AN population being $4.34 \mathrm{mg}$ versus $5.19 \mathrm{mg}$ for those of European descent [102]. This observed difference in warfarin dosing is clinically meaningful and thought to be due, in part, to genetic polymorphisms in the CYP2C9, VKORC1 and CYP4F2 genes [103]. For example, individuals with $C Y P 2 C 9^{*} 2$ or $C Y P 2 C 9^{*} 3$ variant alleles require a lower warfarin dose to achieve therapeutic anticoagulation [104].

In the Indigenous population of Canada, the previously studied $C Y P 2 C 9$ variant allele frequencies were found to be distinct from the European and Asian reference groups, particularly for the Inuit population, where $C Y P 2 C 9^{*} 2,{ }^{*} 3$ and ${ }^{*} 4$ were absent [28]. The MAF of $C Y P 2 C{ }^{*} 2,{ }^{*} 3$ and ${ }^{*} 4$ were $3.0 \%$, $6.0 \%$ and $0.0 \%$, respectively in the FN population (Table 6) [28].

Through deep resequencing to identify novel variants and subsequent genotyping to establish population frequencies, the prevalence of novel and previously known CYP2C9 variants was determined in the Yup'ik AN, AIAN at Southcentral Foundation (SCF) (with multiple AN sub-cultures and an aggregate of AI tribes) and the Confederated Salish and Kootenai Tribes (CSKT) AI populations [32,33]. The MAFs of CYP2C9*2 and *3 were lower in AIAN populations with CYP2C9*2 at $0.3 \%, 5.2 \%$ and $5.2 \%$ in the Yup'ik, SCF and CSKT populations, respectively, compared to European populations at $15.2 \%$ (Table 6) [32,33]. The prevalence of CYP2C9*3 was found to be $2.1 \%, 3.4 \%$ and $2.7 \%$ in the Yup'ik, SCF and CSKT populations, respectively, compared to European populations at $6.6 \%$ (Table 6) [32,33]. CYP2C9*29, a rare coding-region variant, was found at $2.1 \%$ in the Yup'ik population [33]. In another study of AI youth in the Northwestern United States, the MAFs of CYP2C9*2, $* 3$ and $* 5$ were $5.8 \%, 2.7 \%$ and $0.4 \%$, respectively (Table 6 ) [34].

With respect to novel variation, one new novel coding variant, CYP2C9 K119T (Figure 7), was identified in the CSKT population at a frequency of $0.57 \%$ [32]. In addition, two novel coding-region CYP2C9 were identified in the Yup'ik and SCF populations: CYP2C9 M1L (M1L) and CYP2C9 N218I (N218I) (Figure 7) [33]. These two SNVs are of interest due to the fact that they are both coding variants and present at relatively high frequencies in the Yup'ik population; MAFs of M1L and N218I were $6.3 \%$ and $3.8 \%$, respectively, whereas in the SCF population, the MAFs were $1.0 \%$ and $1.4 \%$, respectively (Table 7). The switch from a methionine start codon to leucine for M1L is predicted to confer a PM phenotype in vivo for carriers of the M1L variant by severely slowing or stopping RNA translation and protein production. The N218I variant is also expected to have reduced enzyme activity as it had a Grantham score of 149 [33], where a score greater than 100 indicates that the amino acid substitution is predicted to be damaging. Presently, such in silico predictions cannot be relied upon and additional functional studies are needed [105]. However, there is increased confidence that individuals who are heterozygous or homozygous for the $M 1 L$ variant would have a lower warfarin dose requirement, among phenotypic changes for other CYP2C9 substrates. 
Table 6. Comparison of CYP2C9 allele frequencies in Indigenous North American populations to global populations from the 1000 Genomes Project [20]. $N$ represents the number of alleles. Not shown in the table are CYP2C9*4 (rs56165425) and CYP2C9*6 (rs9332131), as these SNVs were either absent or not tested for in North American Indigenous populations. Global populations are abbreviated as follows: African Ancestry in Southwest US (ASW); Utah residents with Northern and Western European ancestry (CEU); Han Chinese in Beijing, China (CHB); Mexican Ancestry in Los Angeles, California (MXL).

\begin{tabular}{|c|c|c|c|c|c|c|c|}
\hline \multirow{2}{*}{ Country } & \multirow{2}{*}{ Population } & \multirow[b]{2}{*}{$N$} & \multicolumn{4}{|c|}{ CYP2C9 МАF (\%) } & \multirow{2}{*}{ Refs. } \\
\hline & & & $\begin{array}{c}{ }^{*} 2 \\
\text { rs1799853 }\end{array}$ & $\begin{array}{c}* 3 \\
\text { rs1057910 }\end{array}$ & $\begin{array}{c}* 5 \\
\text { rs28371686 }\end{array}$ & $\begin{array}{c}* 29 \\
\text { rs182132442 }\end{array}$ & \\
\hline \multirow{2}{*}{ Canada } & FN & 228 & 3.0 & 6.0 & - & - & [28] \\
\hline & Inuit & 302 & 0.0 & 0.0 & - & - & [28] \\
\hline \multirow{4}{*}{ USA } & Yup'ik & 700 & 0.3 & 2.1 & 0.0 & 2.1 & [33] \\
\hline & AIAN & 718 & 5.2 & 3.4 & 0.0 & 0.0 & [33] \\
\hline & CSKT & 188 & 5.2 & 2.7 & 0.0 & 0.0 & [32] \\
\hline & $\mathrm{AI}$ & 246 & 5.8 & 2.7 & 0.4 & - & [34] \\
\hline \multirow{15}{*}{ Mexico } & Tepehuano & 245 & 0.0 & 7.5 & - & - & [30] \\
\hline & Mexicanera & 76 & 0.0 & 0.0 & - & - & [30] \\
\hline & Huichol & 214 & 0.0 & 3.3 & - & - & [30] \\
\hline & Seri & 38 & 2.6 & 0.0 & - & - & [30] \\
\hline & Guarijío & 30 & 0.0 & 6.7 & - & - & [30] \\
\hline & Mayo & 88 & 5.7 & 9.1 & - & - & [30] \\
\hline & Cora & 162 & 0.0 & 3.7 & - & - & [30] \\
\hline & Tarahumara & 148 & 0.0 & 10.4 & - & - & [30] \\
\hline & Nahua & 424 & 0.7 & 0.4 & - & - & [31] \\
\hline & Teenek & 196 & 0.5 & 0.5 & - & - & [31] \\
\hline & Tarahumara & 104 & 0.0 & 0.0 & - & - & [31] \\
\hline & Purepecha & 96 & 0.0 & 0.0 & - & - & [31] \\
\hline & Huichol & 146 & 0.0 & 0.0 & - & - & [31] \\
\hline & Tepehuano & 198 & 1.0 & 1.5 & 0.0 & - & [29] \\
\hline & $\begin{array}{c}\text { Aggregate } \\
\text { of } \\
\text { Amerindian } \\
\text { tribes }\end{array}$ & 882 & 0.6 & 5.1 & - & - & [23] \\
\hline Multiple & MXL & 128 & 10.2 & 2.3 & 0.0 & 0.0 & [20] \\
\hline \multirow{2}{*}{$\begin{array}{c}\text { Countries } \\
(1000\end{array}$} & $\mathrm{CHB}$ & 206 & 0.0 & 3.9 & 0.0 & 0.5 & [20] \\
\hline & CEU & 198 & 15.2 & 6.6 & 0.0 & 0.0 & [20] \\
\hline Genomes) & ASW & 122 & 4.1 & 1.6 & 2.5 & 0.0 & [20] \\
\hline
\end{tabular}

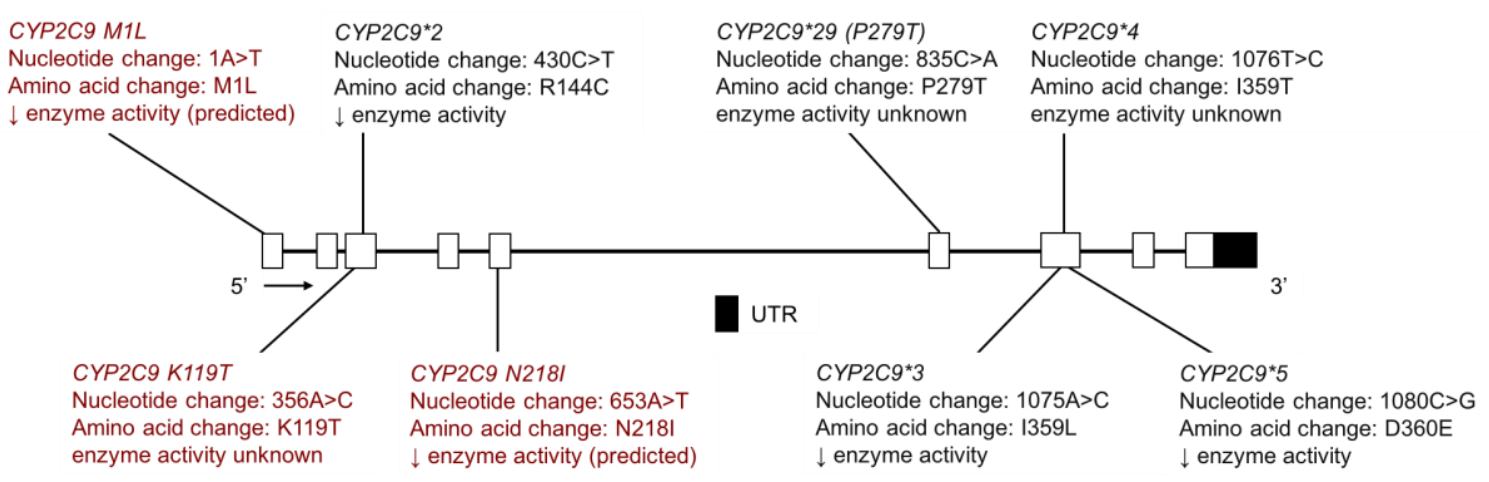

Figure 7. The human $C Y P 2 C 9$ gene and single nucleotide variants (SNVs) tested for in AIAN, FN, Inuit and Amerindian populations. Highlighted in red are novel variants identified by resequencing CYP2C9 in the Yup'ik, AIAN and Confederated Salish and Kootenai Tribes (CSKT) populations. Not shown is $C Y P 2 C 9^{*}$, a frameshift mutation that results in a shortened protein. Open boxes represent exons, lines represent introns and shaded boxes represent UTR. 
Table 7. Comparison of novel CYP2C9 allele frequencies identified by full gene resequencing in AN and AI populations, not found in other world populations.

\begin{tabular}{cccccccc}
\hline \multirow{2}{*}{ Country } & \multirow{2}{*}{ Population } & \multirow{2}{*}{$\boldsymbol{N}$} & \multicolumn{3}{c}{ CYP2C9 MAF (\%) } & \multirow{2}{*}{ Refs. } \\
\cline { 4 - 6 } & & & M1L rsNA & K119T rsNA & N218I rsNA & \\
\hline \multirow{3}{*}{ USA } & Yup'ik & 700 & 6.3 & 0.0 & 3.8 & {$[33]$} \\
& AIAN & 718 & 1.0 & 0.0 & 1.4 & {$[33]$} \\
& CSKT & 188 & 0.0 & 0.57 & 0.0 & {$[32]$} \\
\hline
\end{tabular}

Sosa-Macías et al. determined the CYP2C9*2, *3 and *6 allele frequencies in eight Amerindian populations from Northwest Mexico: Tepehuano, Mexicanera and Huichol from Durango, Cora from Nayarit, Seri, Guarijío and Mayo from Sonora and Tarahumara from Chihuahua [30]. The MAF of CYP2C9*2 in Seris and Mayos was $2.6 \%$ and $5.7 \%$, respectively; this variant was not found in the other six Amerindian populations (Table 6) [30]. With regard to CYP2C9*3, the MAF was $10.4 \%, 9.1 \%, 7.5 \%$, $6.7 \%, 3.7 \%$ and $3.3 \%$ in Tarahumaras, Mayos, Tepehuanos, Guarijíos, Coras and Huicholes, respectively, while it was not detected in Mexicanera or Seri Amerindians (Table 6) [30]. CYP2C9*6 was not detected in any of the eight Amerindian groups studied. Dorado et al. found that the MAF of CYP2C9*2 and *3 in the Tepehuano population was $1.0 \%$ and $1.5 \%$, respectively, while CYP2C ${ }^{*} 4$, *5 and *6 were not detected (Table 6) [29]. Castelán-Martínez et al. tested for CYP2C9*2 and CYP2C9*3 in five Amerindian groups: Nahua from Central Mexico, Teenek from the Huasteca Potosina region, Tarahumara from Chihuahua, Purepecha from Michoacan and Huichol from Nayarit [31]. In the Nahua and Teenek groups, the CYP2C9*2 MAF was $0.7 \%$ and $0.5 \%$, respectively and the $C Y P 2 C 9 * 3 \mathrm{MAF}$ was $0.4 \%$ and $0.5 \%$, respectively (Table 6) [31]. The CYP2C9*2 and *3 alleles were absent from the Tarahumara, Purepecha and Huichol Amerindian groups [31].

With regard to $\mathrm{CYP}_{2} \mathrm{C9}^{*} 2$ in the Tepehuano and Tarahumara populations, the results reported by Dorado et al. Sosa-Macías et al. and Castelán-Martínez et al. are in agreement, with this allele being absent or presenting at a low frequency, compared to Mestizos (6.9\%) [29-31]. However, there is a notable difference in $\mathrm{CYP2C} 9^{*} 3$ allele frequencies reported by these authors for the Tepehuano and Tarahumara populations. Dorado et al. included 99 Tepehuanos, Castelán-Martínez et al. included 104 Tarahumaras and Sosa-Macías et al. included 127 Tepehuanos and 74 Tarahumaras. The small sample sizes may contribute to the observed difference in allele frequency.

De Andrés et al. performed genotyping and phenotyping, using losartan as a probe substrate as part of a cocktail, in Amerindian population including the Tarahumara, Tepehuano, Mexicanera, Huichol, Cora, Seri, Mayo and Guarijío groups [23]. The ratio of losartan to losartan carboxylic acid was significantly greater in $\mathrm{CYP} 2 \mathrm{C}^{*} 2$ or $* 3$ homozygotes or carriers, compared to those with the reference genotype [23]. However, there were also three individuals whose high parent to metabolite could not be explained by their genotype, suggesting that there may be unidentified rare variants that confer PM phenotype in this Amerindian population [23].

\subsection{CYP2C19}

The CYP2C19 enzyme plays an important role in the metabolism of antiplatelet agents (e.g., clopidogrel) [106], proton pump inhibitors (e.g., omeprazole) [107], tricyclic antidepressants [108,109], selective serotonin reuptake inhibitors [110-113] and benzodiazepines [114]. CYP2C19*2 and *3 alleles define the current PM phenotype status (Figure 8), with markedly different allele frequencies across different ethnic populations. The CYP2C19*17 variant is a gain-of-function allele, resulting in higher enzyme activity (Figure 8) [115]. CYP2C19 catalyzes the 4'-hydroxylation of (S)-mephenytoin, a probe substrate for CYP2C19 [116,117]. The CYP2C19 PM phenotype is associated with a reduced ability to metabolize (S)-mephenytoin [118]. Thus, PMs eliminate racemic mephenytoin more slowly than EMs and urinary $4^{\prime}$-hydroxymephenytoin and $S / R$ mephenytoin enantiomeric ratio was used in the past to distinguish between CYP2C19 EMs and PMs [119]. 
Nowak et al. reported that in FNs, the CYP2C19*2 allelic variant was found at $19.1 \%$, while CYP2C19*3 was not detected (Table 8) [26]. Jurima-Romet et al. conducted CYP2C19 genotyping and phenotyping, based on the mephenytoin S/R enantiomeric ratio, in Inuit peoples in Canada [35]. The CYP2C19*2 allele frequency was $12 \%$, while CYP2C19*3 was not detected in this Inuit population (Table 8). Subjects ingested a single dose of $100 \mathrm{mg}(R, S)$-mephenytoin and collected urine for $12 \mathrm{~h}$. Urinary $\mathrm{S} / \mathrm{R}$ mephenytoin enantiomeric ratio was used to distinguish between EMs and PMs, where $S / R$ ratio $\geq 1.0$ indicated PM phenotype and S/R ratio $\leq 0.5$ indicated EM phenotype. Genotype results were in agreement with phenotype results and as expected, individuals classified as PMs did not have detectable levels urinary $4^{\prime}$-hydroxymephenytoin [35].

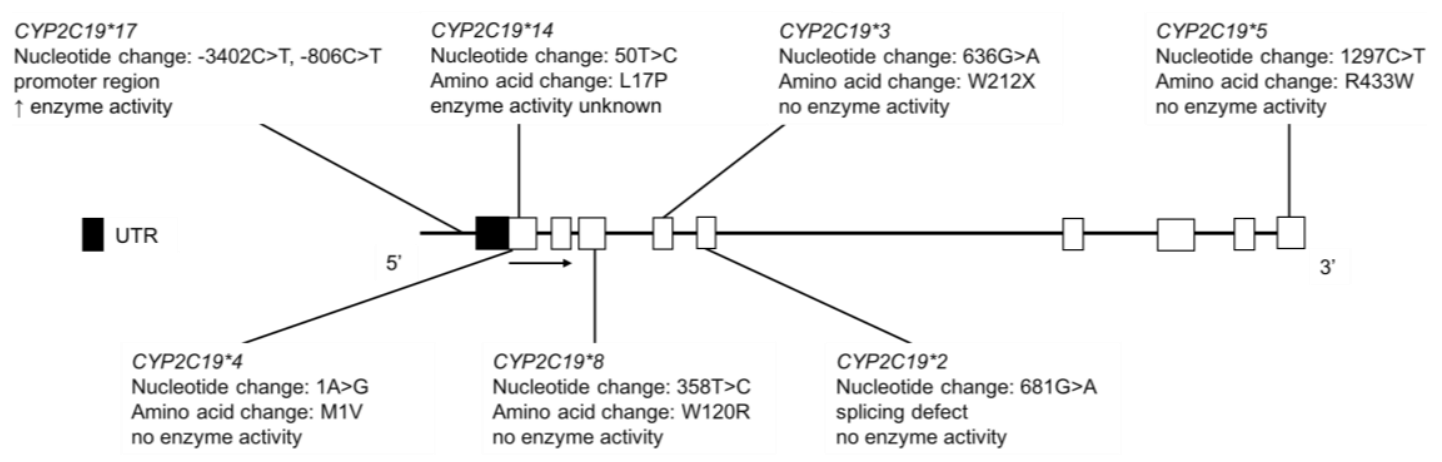

Figure 8. The human $C Y P 2 C 19$ gene and SNVs genotyped for in AI, FN, Inuit and Amerindian populations. Open boxes represent exons, lines represent introns and shaded boxes represent UTR.

Table 8. Comparison of CYP2C19 allele frequencies in Indigenous North American populations to global populations from the 1000 Genomes Project [20]. For alleles defined by multiple variants, the frequencies reported in Zhou et al. using LDLink software [81] were used. $N$ represents the number of alleles. Not shown in the table are CYP2C19*5 (rs56337013) and ${ }^{*}$ CYP2C19*14 (rs55752064), as they were not found in any Amerindian populations and not genotyped for in Indigenous peoples of Canada or AIs.

\begin{tabular}{|c|c|c|c|c|c|c|c|c|}
\hline \multirow{2}{*}{ Country } & \multirow[b]{2}{*}{ Population } & \multirow[b]{2}{*}{$N$} & \multicolumn{5}{|c|}{ CYP2C19 МАF (\%) } & \multirow[b]{2}{*}{ Refs. } \\
\hline & & & $\begin{array}{c}* 2 \\
\text { rs4244285 }\end{array}$ & $\begin{array}{c}* 3 \\
\text { rs49868933 }\end{array}$ & $\begin{array}{c}{ }^{*} 4 \\
\text { rs28399504 }\end{array}$ & $\begin{array}{c}* 8 \\
\text { rs41291556 }\end{array}$ & $\begin{array}{c}{ }^{*} 17 \\
\text { rs12248560 }\end{array}$ & \\
\hline \multirow{2}{*}{ Canada } & $\mathrm{FN}$ & 230 & 19.1 & 0.0 & - & - & - & [26] \\
\hline & Inuit & 180 & 12.0 & 0.0 & - & - & - & [35] \\
\hline \multirow[b]{2}{*}{ USA } & Sioux & 196 & 11.2 & 0.0 & - & - & 8.7 & [36] \\
\hline & $\mathrm{AI}$ & 246 & 11.5 & - & 1.3 & 0.0 & 11.1 & [34] \\
\hline \multirow{6}{*}{ Mexico } & Tarahumara & 168 & 31.0 & 0.0 & 0.0 & - & - & [37] \\
\hline & Purepecha & 202 & 5.4 & 0.0 & 0.0 & - & - & [37] \\
\hline & Tojolabal & 136 & 3.6 & 0.0 & 0.0 & - & - & [37] \\
\hline & Tzotzil & 176 & 5.6 & 0.0 & 0.0 & - & - & [37] \\
\hline & Tzeltal & 40 & 0.0 & 0.0 & 0.0 & - & - & [37] \\
\hline & $\begin{array}{c}\text { Aggregate of } \\
\text { Amerindian tribes }\end{array}$ & 880 & 12.0 & 0.2 & 0.0 & - & 2.2 & [23] \\
\hline Multiple & MXL & 128 & 12.5 & 0.0 & 0.8 & 0.0 & 11.7 & [20] \\
\hline \multirow{3}{*}{$\begin{array}{l}\text { Countries } \\
\text { (1000 } \\
\text { Genomes) }\end{array}$} & $\mathrm{CHB}$ & 206 & 33.5 & 4.4 & 0.5 & 0.0 & 2.4 & [20] \\
\hline & CEU & 198 & 13.1 & 0.0 & 0.0 & 1.5 & 22.2 & [20] \\
\hline & ASW & 122 & 13.9 & 0.0 & 0.0 & 0.8 & 19.7 & [20] \\
\hline
\end{tabular}

Clopidogrel is a prodrug that is bioactivated by multiple P450s enzymes (including CYP2C19) to its active metabolite, which acts as an antiplatelet agent by irreversibly inhibiting the P2Y12 adenosine diphosphate receptor on platelets [106]. CYP2C19 genetic variation has been associated with the fraction metabolized and clinical response to clopidogrel [120]. In the Oglala Sioux Tribe of South Dakota, the MAFs for CYP2C19*2, ${ }^{*} 3$ and ${ }^{*} 17$ were $11.2 \%, 0.0 \%$ and $8.7 \%$, respectively 
(Table 8) [36]. P2Y12 reaction units (PRU) were used to evaluate the pharmacodynamic effect of clopidogrel, with lower values representing reduced platelet aggregation and higher efficacy of clopidogrel. Although PRU was not found to be significantly associated with genotype, the median PRU of 194 (range 29-400) is similar to values reported for other groups [36].

In a study examining CYP2C19 variant alleles in AI children, the frequencies of CYP2C19*2, 4 and ${ }^{*} 17$ were $11.5 \%, 1.3 \%$ and $11.1 \%$, respectively (Table 8) [34]. CYP2C19*8 and CYP2C19*14 were not present in the AI population studied and $\mathrm{CYP} 2 \mathrm{C} 19^{*} 3$ was not tested. Currently, nothing is known about genotype-drug disposition and response phenotype associations in AN populations.

With regards to CYP2C19 variation in Amerindians of Mexico, Salazar-Flores et al. performed genotyping in Tarahumaras from Chihuahua, Purepechas from Michoacán, Tojolabales, Tzotziles and Tzeltales from Chiapas and Tepehuanos from Durango [37]. The CYP2C19*2 MAF was reported as 31\%, 5.4\%, 3.6\%, 5.6\% and 0.0\% in Tarahumaras, Purepechas, Tojolabales, Tzotziles and Tzeltales, respectively (Table 8) [37]. The high allele frequency in the Tarahumara population is of particular interest clinically, as this predicts that a substantial portion of the population would be CYP2C19 PMs. CYP2C19*3, *4 and *5 were not detected in any of the Amerindian populations studied [37]. In an Amerindian population including the Tarahumara, Tepehuano, Mexicanera, Huichol, Cora, Seri, Mayo and Guarijío groups, de Andrés et al. reported the MAFs of CYP2C19*2, ${ }^{*} 3$ and ${ }^{*} 17$ as $12.0 \%, 0.2 \%$ and $2.2 \%$, respectively (Table 8) [23]. CYP2C19*4 and $* 5$ were not detected in the population studied [23]. CYP2C19 phenotype was determined using omeprazole as a probe substrate as part of a drug cocktail. The ratio of omeprazole to 5-hydroxyomeprazole was significantly greater in individuals with the PM conferring variants, $\mathrm{CYP} 2 \mathrm{C} 19^{*} 2$ or *3, compared to those with the reference genotype [23]. There were some individuals whose genotype did not correspond to their phenotype, which the authors suggest may be due to population-specific alleles not identified in other populations [23].

\section{7. $C Y P 2 D 6$}

The CYP2D6 enzyme metabolizes many basic drugs including opioids [121,122], antidepressants (e.g., nortriptyline and fluoxetine) $[108,111,123,124]$, antipsychotics (e.g., risperidone) $[125,126]$ and B-blockers (e.g., metoprolol) [127-129]. It is another example of a polymorphic enzyme with highly penetrant null (loss-of-function) allelic variants conferring a PM phenotype or copy number variation resulting in a UM phenotype. Individuals homozygous or compound heterozygous for the CYP2D $6^{*} 3$, ${ }^{*} 4, * 5$, or *6 variants exhibit no enzyme activity (Figure 9), while those with CYP2D6*1 or *2 gene duplication have more CYP2D6 protein with resulting higher enzymatic activity. This is clinically relevant for codeine, which is metabolized to morphine by CYP2D6. CYP2D6 PMs may experience an inadequate analgesic effect while UMs are at risk of morphine toxicity $[130,131]$. This is particularly important for the pediatric population for which codeine use was common and so in 2013 a US Food and Drug Administration Black Box Warning was issued for the drug. A structurally related drug, dextromethorphan (DEX), is O-demethylated by CYP2D6 to dextrorphan (DXO) and, therefore, the metabolic ratio of DEX/DXO can be used to differentiate between CYP2D6 phenotypes [132,133].

In Inuit peoples in Canada, the allele frequency of CYP2D $6^{*} 4$ was $6.7-8.3 \%$; the CYP2D $6^{*} 10 \mathrm{MAF}$ was $2.2 \%$ and the CYP2D $6 * 3$ and ${ }^{*} 6$ alleles were not detected (Table 9) [38]. Phenotyping, based on the urinary DEX/DXO metabolic ratio, was also performed. Study participants ingested a single dose of $30 \mathrm{mg}$ dextromethorphan hydrobromide and collected urine overnight. Phenotype results were in agreement with genotype and furthermore, individuals classified as PMs had lower recoveries of DXO as well as other CYP2D6-mediated metabolites, compared to EMs. Notably, the frequency of the CYP2D $6^{*} 4$ allele in the Inuit population was significantly lower than the MAF reported in the European population $(23 \%)[134,135]$ and significantly greater than in the Asian population $(<1.0 \%)[136,137]$. 
Table 9. Comparison of CYP2D6 allele frequencies Indigenous North American populations to global populations from the 1000 Genomes Project [20]. N represents the number of alleles. Not shown is CYP2D6*7 (rs503086), as it was not detected or not tested for in the Indigenous populations studied. Global populations are abbreviated as follows: African Ancestry in Southwest US (ASW); Utah residents with Northern and Western European ancestry (CEU); Han Chinese in Beijing, China (CHB); Mexican Ancestry in Los Angeles, California (MXL). For alleles not captured by 1000 Genomes (noted by $\ddagger$ ), the frequencies were extracted from Exome Aggregation Consortium [80] and for alleles defined by multiple variants, the frequencies reported in Zhou et al. [21] using LDLink software [81] were used.

\begin{tabular}{|c|c|c|c|c|c|c|c|c|c|c|c|c|c|}
\hline \multirow[b]{2}{*}{ Country } & \multirow[b]{2}{*}{ Population } & \multirow[b]{2}{*}{$N$} & \multicolumn{10}{|c|}{ CYP2D6 MAF (\%) } & \multirow[b]{2}{*}{ Refs. } \\
\hline & & & $\begin{array}{c}* 2 \\
\text { rs16947, } \\
\text { rs1135840 }\end{array}$ & $\begin{array}{c}* 3 \\
\text { rs35742686 }\end{array}$ & $\begin{array}{c}{ }^{*} 4 \\
\text { rs3892097 }\end{array}$ & $* 5$ & $\begin{array}{c}{ }^{*} 6 \\
\text { rs5030655 }\end{array}$ & $\begin{array}{c}* 8 \\
\text { rs5030865 }\end{array}$ & $\begin{array}{c}{ }^{*} 10 \\
\text { rs1065852, } \\
\text { rs1135840 }\end{array}$ & $\begin{array}{c}{ }^{*} 17 \\
\text { rs16947, } \\
\text { rs28371706 }\end{array}$ & $\begin{array}{c}* 35 \\
\text { rs769258, } \\
\text { rs16947, } \\
\text { rs1135840 }\end{array}$ & $\begin{array}{c}{ }^{*} 41 \\
\text { rs28371725 }\end{array}$ & \\
\hline \multirow[b]{2}{*}{ Canada } & FN & 190 & - & 0.0 & 3.0 & - & - & - & 3.0 & - & - & - & [39] \\
\hline & Inuit & 180 & - & 0.0 & $6.7-8.3$ & - & - & - & 2.2 & - & - & - & [38] \\
\hline \multirow[b]{2}{*}{ USA } & $\mathrm{AI}$ & 246 & 25.2 & 0.0 & 14.6 & 2.8 & 0.8 & - & 2.0 & 0.0 & 0.4 & 6.9 & [34] \\
\hline & CSKT & 374 & 23.4 & 0.3 & 20.9 & 1.3 & 0.0 & - & 1.3 & 0.0 & 1.1 & 11.2 & [32] \\
\hline \multirow{17}{*}{ Mexico } & Tepehuano & 198 & 20.0 & 0.0 & 0.6 & 0.5 & 0.0 & - & 0.0 & - & 0.0 & 1.0 & {$[41,42]$} \\
\hline & Tarahumara & 176 & - & 0.0 & 7.3 & - & 0.0 & 0.0 & - & - & - & - & [37] \\
\hline & Purepecha & 170 & - & 0.0 . & 2.9 & - & 0.0 & 0.0 & - & - & - & - & [37] \\
\hline & Tojolabal & 86 & - & 0.0 & 1.2 & - & 0.0 & 0.0 & - & - & - & - & [37] \\
\hline & Tzotzil & 112 & - & 0.0 & 2.7 & - & 0.0 & 0.0 & - & - & - & - & [37] \\
\hline & Tzeltal & 38 & - & 0.0 & 5.3 & - & 0.0 & 0.0 & - & - & - & - & [37] \\
\hline & Tarahumara & 148 & 21.0 & 0.0 & 11.5 & 3.4 & 0.0 & - & 0.7 & 0.0 & 0.0 & 4.1 & [43] \\
\hline & Tepehuano & 258 & 20.0 & 0.0 & 0.3 & 0.4 & 0.0 & - & 0.0 & 0.0 & 0.0 & 0.4 & [43] \\
\hline & Huichol & 214 & 21.0 & 0.0 & 7.0 & 0.0 & 0.0 & - & 0.0 & 0.0 & 0.0 & 0.0 & [43] \\
\hline & Mexicanera & 78 & 22.0 & 0.0 & 0.0 & 1.3 & 0.0 & - & 0.0 & 0.0 & 0.0 & 0.0 & [43] \\
\hline & Cora & 162 & 28.0 & 0.0 & 1.0 & 1.2 & 0.0 & - & 0.0 & 0.0 & 0.0 & 1.0 & [43] \\
\hline & Seri & 38 & 5.0 & 0.0 & 21.0 & 0.0 & 0.0 & - & 0.0 & 0.0 & 0.0 & 0.0 & [43] \\
\hline & Guarijío & 30 & 23.0 & 0.0 & 3.0 & 0.0 & 0.0 & - & 0.0 & 0.0 & 0.0 & 0.0 & [43] \\
\hline & Mayo & 88 & 10.0 & 0.0 & 8.0 & 0.0 & 3.0 & - & 0.0 & 0.0 & 0.0 & 3.0 & [43] \\
\hline & Mayan Lacandon & 308 & 20.8 & 0.0 & 10.4 & 0.0 & 0.0 & - & 0.6 & 0.0 & 0.3 & 1.3 & [44] \\
\hline & Tzotzil and Tzeltal & 220 & 17.3 & 0.5 & 5.5 & 3.6 & 0.0 & - & 0.5 & 0.5 & 0.0 & 0.0 & [45] \\
\hline & $\begin{array}{c}\text { Aggregate of Amerindian } \\
\text { tribes }\end{array}$ & 758 & 18.9 & - & 4.5 & 1.0 & 0.1 & - & 0.1 & - & - & 1.1 & [23] \\
\hline \multirow{4}{*}{$\begin{array}{c}\text { Multiple } \\
\text { Countries } \\
(1000 \\
\text { Genomes })\end{array}$} & $\begin{array}{c}\text { MXL } \\
\text { Latino } \ddagger\end{array}$ & $\begin{array}{c}128 \\
9768 \ddagger\end{array}$ & - & 0.0 & 12.5 & - & 0.0 & 0.0 & - & - & - & 1.6 & $\begin{array}{c}{[20]} \\
{[80]^{\ddagger}}\end{array}$ \\
\hline & $\begin{array}{c}\text { CHB } \\
\text { East Asian } \neq\end{array}$ & $\begin{array}{c}206 \\
7968 \ddagger\end{array}$ & $14.0^{\ddagger}$ & 0.0 & 0.5 & $6.5^{\ddagger}$ & 0.0 & 0.5 & $58.7 \ddagger$ & $0.0 \ddagger$ & - & 3.4 & $\begin{array}{c}{[20]} \\
{[21,80]^{\ddagger}}\end{array}$ \\
\hline & $\begin{array}{c}\text { CEU } \\
\text { European } \ddagger\end{array}$ & $\begin{array}{c}198 \\
56,352 \\
\ddagger\end{array}$ & $34.3^{\ddagger}$ & 2.0 & 22.7 & $3.0 \ddagger$ & 2.0 & 0.0 & $0.2 \ddagger$ & $<0.1 \ddagger$ & - & 12.1 & $\begin{array}{c}{[20]} \\
{[21,80]^{\ddagger}}\end{array}$ \\
\hline & $\begin{array}{c}\text { ASW } \\
\text { African } \ddagger\end{array}$ & $\begin{array}{c}122 \\
7304 \ddagger\end{array}$ & $26.7 \ddagger$ & 1.6 & 12.3 & $4.0 \ddagger$ & 0.8 & 0.0 & $3.2 \ddagger$ & $19.7 \ddagger$ & - & 1.6 & $\begin{array}{c}{[20]} \\
{[21,80] \ddagger}\end{array}$ \\
\hline
\end{tabular}




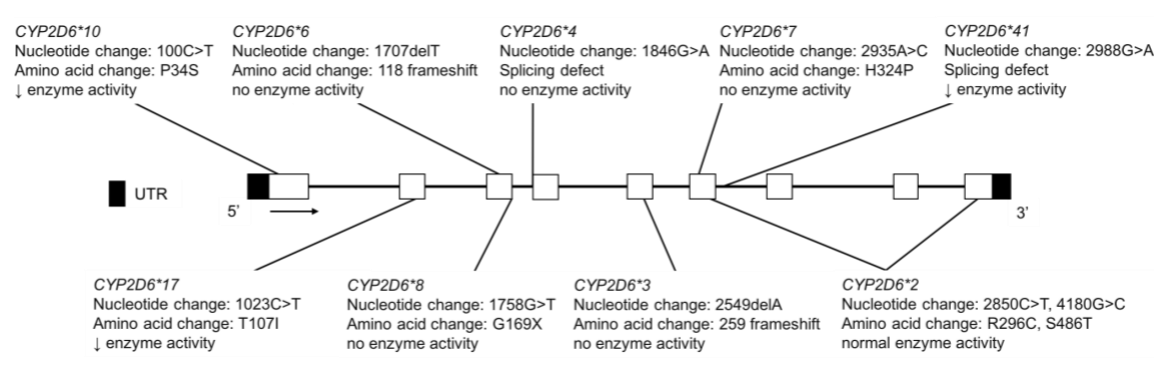

Figure 9. The human CYP2D6 gene and variants tested for in the Inuit, FN, CSKT, AI youth and Amerindian populations. For variants that are part of a haplotype group, only the diagnostic SNVs commonly tested are shown. Not shown are copy number variations, CYP2D6*5, a full gene deletion and CYP2D6*35, which has normal enzyme activity and is the result of multiple nucleotide changes $(-1584 \mathrm{C}>\mathrm{G}, 31 \mathrm{G}>\mathrm{A}, 1661 \mathrm{G}>\mathrm{C} ; 2850 \mathrm{C}>\mathrm{T}$ and 4180G $>\mathrm{C})$ and amino acid changes (V11M, R296C and $\mathrm{S} 486 \mathrm{~T}$ ) in multiple exons. Open boxes represent exons, lines represent introns and shaded boxes represent UTR.

CYP2D6 genotype, as well as phenotype using the O-demethylation ratio of DEX [138], was determined in a FN population [39]. The MAFs of $C Y P 2 D 6{ }^{*} 3,{ }^{*} 4$ and ${ }^{*} 10$ were $0.0,3.0$ and $3.0 \%$, respectively (Table 9) [39]. Interestingly, the one individual identified as a CYP2D6 PM by phenotyping with DEX was not found to have a CYP2D $6^{*} 4 /^{*} 4$ genotype. This suggests that the PM phenotype could be attributed to a null allele not tested for in this study or a novel loss-of-function variant.

In the CSKT population, the CYP2D $6^{*} 1$ frequency was $37.6 \%, C Y P 2 D 6^{*} 2$ occurred at a frequency of $23.4 \%$ and copy number variation conferring UM phenotype had a frequency of $1.1 \%$ [32]. The reported frequencies of the PM conferring variants CYP2D $6{ }^{*} 3,{ }^{*} 4, * 5$ and ${ }^{*} 6$ were $0.3 \%, 20.9 \%, 1.3 \%$ and $0.0 \%$, respectively (Table 9). The reduced activity variants conferring IM phenotype, CYP2D 6*10, ${ }^{*} 17$ and ${ }^{*} 41$, had frequencies of $1.3 \%, 0.0 \%$ and $11.2 \%$, respectively (Table 9). These allele frequencies are similar to the findings of McGrane and Loveland who performed pharmacogenetic testing in Northwest AI youth and reported MAFs of CYP2D 6*3, ${ }^{*} 4,{ }^{*} 5,{ }^{*} 6,{ }^{*} 10,{ }^{*} 17$ and ${ }^{*} 41$ as $0.0 \%, 14.6 \%, 2.8 \%, 0.8 \%$, $2.0 \%, 0.0 \%$ and $6.9 \%$, respectively (Table 9) [34]. The relatively high frequencies for CYP2D $6^{*} 4$ and CYP2D $6^{*} 41$ could have clinical implications, particularly with medications that require bioactivation by CYP2D6 to an active metabolite to be clinically effective. Beyond codeine, another such drug is tamoxifen, an estrogen receptor antagonist used to prevent and treat estrogen-dependent breast cancer. CYP2D6 is the primary enzyme responsible for metabolizing tamoxifen to endoxifen, a major active metabolite responsible for much of tamoxifen's therapeutic effect $[139,140]$. Therefore, it is important to understand the distribution of CYP2D6 activity within different patient populations. In the Northwest CSKT and AI youth populations, the overall prevalence of low activity CYP2D6, including both PMs and IMs, was $9.1 \%$ and $20.3 \%$, respectively.

Salazar-Flores et al. performed CYP2D6 genotyping in Tarahumaras from Chihuahua, Purepechas from Michoacán, Tojolabales, Tzotziles and Tzeltales from Chiapas and Tepehuanos from Durango [37]. The MAFs reported for $C Y P 2 D 6^{*} 4$ were $7.3 \%, 2.9 \%, 1.2 \%, 2.7 \%$ and $5.3 \%$ for Tarahumaras, Purepechas, Tojolabales, Tzotziles and Tzeltales, respectively (Table 9) [37]. CYP2D 6*3, ${ }^{*} 6,{ }^{*} 7$ and ${ }^{*} 8$ were not detected in any of the Amerindian populations studied [37]. The CYP2D6 genotype results from Perez-Paramo et al. in Tzotziles and Tzeltales, López-López et al. in Mayan Lacandones, Lazalde-Ramos et al. in Tarahumaras, Tepehuanos, Huicholes, Mexicaneros Coras, Seris, Guarijíos and Mayos, as well as two studies by Sosa-Macías et al. in Tepehuanos further support previous findings that the frequency of CYP2D6 inactive alleles is low in most Amerindian populations (Table 9) [41-43]. These MAFs predict a low frequency of CYP2D6 PMs in these Amerindian populations. Sosa-Macías et al. and Lares-Asseff et al. investigated the CYP2D6 phenotype in Tepehuanos using DEX/DXO metabolic ratio and found that no Tepehuanos were classified as CYP2D6 PMs, as expected based on the allele frequencies reported by multiple studies [40,41]. The frequency of CYP2D6 UMs, based on 
CYP2D $6^{*} 1$ or *2 gene duplication, varied depending on the Amerindian population studied and the location of the reference Mestizo population [23,43-45].

The genotype results reported by de Andrés et al. in an Amerindian population including the Tarahumara, Tepehuano, Mexicanera, Huichol, Cora, Seri, Mayo and Guarijío groups, were consistent with previously published findings that $C Y P 2 D 6$ variants conferring PM status are rare in the Amerindian population [23]. Regarding CYP2D6 multiplications, the frequency of $w t x N, * 2 x N$ and ${ }^{*} 4 x N$ were $4.7,1.1$ and $0.1 \%$, respectively [23]. CYP2D6 phenotype was also determined using the DEX/DXO ratio, with a significantly greater parent to metabolite ratio for individuals with reduced activity or null CYP2D6 variants [23]. As with the other P450 drug metabolizing enzymes evaluated in this study, there was some discordance between genotype and phenotype. Further studies are necessary to identify and characterize variants that may impact the activity of important drug metabolizing enzymes including CYP2D6.

\subsection{CYP2E1}

The CYP2E1 enzyme metabolizes ethanol [141-143], tobacco-related nitrosamines [144], as well as other xenobiotics (e.g., acetaminophen) [145,146]. CYP2E1 is also induced by ethanol, increasing alcohol metabolism in cases of chronic ethanol consumption [146-148]. CYP2E1*1D has been associated with greater CYP2E1 induction by ethanol in individuals with at least one copy of the allele (Figure 10) [149]. The $C Y P 2 E 1 * 5 B$ allele, also referred to as $C Y P 2 E 1^{*} C 2$, has been associated with increased enzyme activity (Figure 10) [150,151].

The frequency of $C Y P 2 E 1^{*} 1 D$ was reported to be $9.3 \%$ in the FN population (Table 10 ), which is significantly higher than that seen in European Canadians (2.1\%) [46]. Furthermore, FN individuals dependent on alcohol (as defined by DSM-IV) had a higher frequency of the CYP2E1*1D allele, compared to non-alcohol dependent FNs [46]. This same trend was found in Europeans and Southeast Asians [46]. CYP2E1*1D genotype was also associated with nicotine dependence in FNs, however further studies are needed to elucidate potential mechanisms responsible for this relationship [46].

Table 10. Comparison of CYP2E1 allele frequencies Indigenous North American populations to global populations from the 1000 Genomes Project [20]. N represents the number of alleles. Global populations are abbreviated as follows: African Ancestry in Southwest US (ASW); Utah residents with Northern and Western European ancestry (CEU); Han Chinese in Beijing, China (CHB); Mexican Ancestry in Los Angeles, California (MXL).

\begin{tabular}{cccccc}
\hline \multirow{2}{*}{ Country } & \multirow{2}{*}{ Population } & \multirow{2}{*}{$\boldsymbol{N}$} & \multicolumn{2}{c}{ CYP2E1 MAF (\%) } & \multirow{2}{*}{ Refs. } \\
\cline { 4 - 5 } & & & ${ }^{*} \mathbf{1 D}$ & ${ }^{*}$ 5B rs2031920 & \\
\hline Canada & FN & 228 & 9.3 & - & {$[46]$} \\
\hline Mexico & Huichol & 198 & - & 51.5 & {$[47]$} \\
\hline \multirow{2}{*}{ Multiple } & MXL & 128 & - & 15.6 & {$[20]$} \\
Countries (1000 & CHB & 206 & - & 23.8 & {$[20]$} \\
Genomes) & CEU & 198 & - & 6.1 & {$[20]$} \\
& ASW & 122 & - & 1.6 & {$[20]$} \\
\hline
\end{tabular}

The MAF of the CYP2E1 -1295G>C variant was determined to be $51.5 \%$ in Huichols, an Amerindian population of Western-Central Mexico (Table 10) [47]. This frequency is very high compared to the Mexicans from Western Mexico (16.1\%) and Europeans (1.7\%) [47,152]. The CYP2E1 $-1295 \mathrm{G}>\mathrm{C}$ variant is of interest when considering the metabolism of ethanol, as well as other CYP2E1 substrates and further studies would be useful to establish the clinical relevance of CYP2E1 variation across diverse populations. 


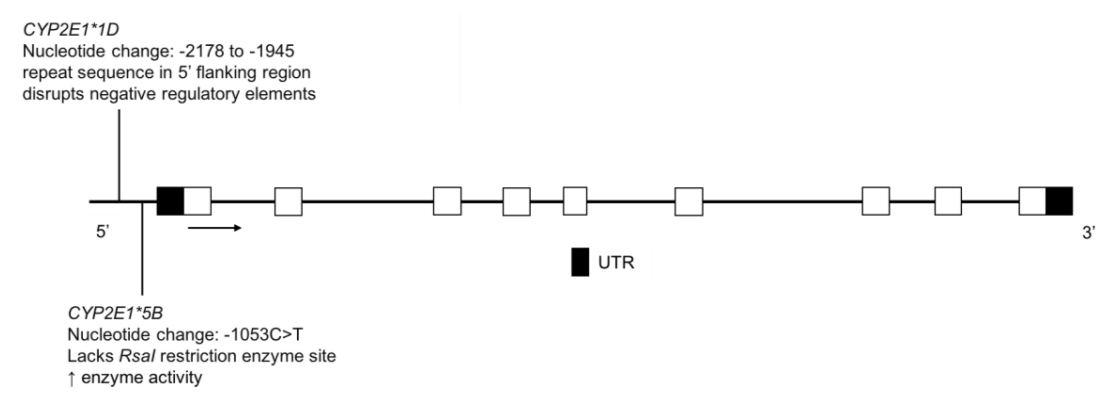

Figure 10. The human CYP2E1 gene and the variants identified in the FN and Amerindian populations. Open boxes represent exons, lines represent introns and shaded boxes represent UTR.

\subsection{CYP3A4 and CYP3A5}

The CYP3A4 and CYP3A5 enzymes have overlapping substrate specificity and together, they control the clearance of approximately $50 \%$ of all drugs eliminated primarily through P450-mediated biotransformation [15]. CYP3A4 protein is present in almost all adults, whereas CYP3A5 protein expression varies across different ethnic groups [153]; polymorphisms in the genes encoding these proteins are shown in Figures 11 and 12. The CYP3A5 enzyme is expressed in individuals having at least one $C Y P 3 A 5^{*} 1$ allele, while those with two inactive alleles, $C Y P 3 A 5^{*} 3,{ }^{*} 6$, or ${ }^{*}$, encode a nonfunctional protein (Figure 12); the PM phenotype is most common in Europeans and less so in Asians and African Americans [154,155]. The CYP3A4*22 variant is also associated with reduced CYP3A4 protein levels and enzyme function (Figure 11) [156-158], as are rare deleterious coding variants [159]. The $C Y P 3 A 4^{*} 1 B$ and $C Y P 3 A 4^{*} 1 G$ alleles (Figure 11) reportedly affect gene transcription but functional effects are unclear, as the data are mixed and interpretation is complicated by high linkage disequilibrium with $C Y P 3 A 5^{*} 1$ [160-162].

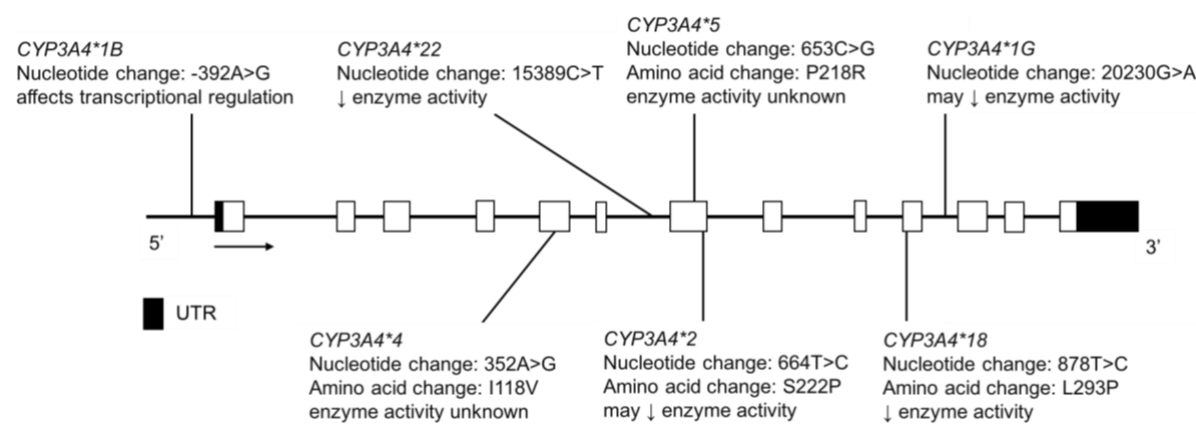

Figure 11. The human CYP3A4 gene and SNVs tested for in the CSKT and Amerindian populations. Novel non-coding variants are not shown. Open boxes represent exons, lines represent introns and shaded boxes represent UTR.

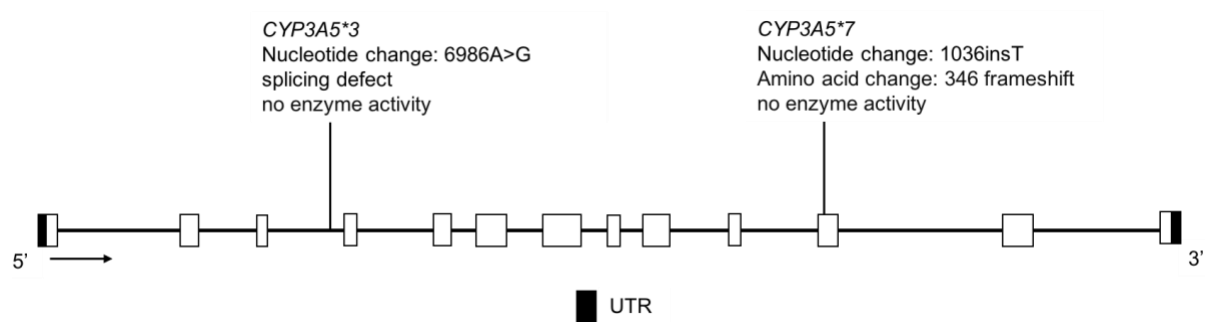

Figure 12. The human CYP3A5 gene and the variants tested for in the CSKT population. Not shown is $C Y P 3 A 5^{*} 6$, where alternative splicing results in exon 7 skipping. Open boxes represent exons, lines represent introns and shaded boxes represent UTR. 
In the CSKT population, resequencing followed by subsequent genotyping identified four novel CYP3A4 SNVs-three intronic and one in the 5 ' UTR region. The known CYP3A4 variants, ${ }^{*} 1 B,{ }^{*} 22$ and ${ }^{*} 1 G$ were found at frequencies of $2.2 \%, 2.4 \%$ and $26.8 \%$, respectively (Table 11) [32]. This combination of allele frequencies may result in haplotypes conferring altered enzyme activity, which remains to be tested. With regard to CYP3A5 in the CSKT population, CYP3A5*1 was detected at a frequency of $7.5 \%, C Y P 3 A 5 * 3$ at $92.5 \%$, while $C Y P 3 A 5^{*} 6$ and ${ }^{*} 7$ were not detected (Table 12 ). These data suggest that $14.9 \%$ of CSKT individuals express CYP3A5, contributing to their total CYP3A metabolic activity.

Table 11. Comparison of CYP3A4 allele frequencies Indigenous North American populations to global populations from the 1000 Genomes Project [20]. $N$ represents the number of alleles. Not shown are CYP3A4*2 (rs55785340), CYP3A4*4 (rs55951658) and CYP3A4*8 (72552799), as these variants were either not detected or not tested for in the Indigenous populations studied. Global populations are abbreviated as follows: African Ancestry in Southwest US (ASW); Utah residents with Northern and Western European ancestry (CEU); Han Chinese in Beijing, China (CHB); Mexican Ancestry in Los Angeles, California (MXL).

\begin{tabular}{|c|c|c|c|c|c|c|c|}
\hline \multirow{2}{*}{ Country } & \multirow{2}{*}{ Population } & \multirow[b]{2}{*}{$N$} & \multicolumn{4}{|c|}{ СУРЗА4 MAF (\%) } & \multirow[b]{2}{*}{ Refs. } \\
\hline & & & $\begin{array}{c}{ }^{*} 1 B \\
\text { rs2 } 2740574\end{array}$ & $\begin{array}{c}{ }^{*} 1 G \\
\text { rs2242480 }\end{array}$ & $\begin{array}{c}* 5 \\
\text { rs55901263 }\end{array}$ & $\begin{array}{c}* 22 \\
\text { rs35599367 }\end{array}$ & \\
\hline USA & CSKT & 188 & 2.2 & 26.8 & 0.0 & 2.4 & [32] \\
\hline \multirow[t]{2}{*}{ Mexico } & $\begin{array}{l}\text { Tepehuano } \\
\text { Aggregate }\end{array}$ & 200 & 8.0 & - & 0.0 & - & [48] \\
\hline & $\begin{array}{l}\text { of } \\
\text { Amerindian } \\
\text { tribes }\end{array}$ & 420 & 4.8 & - & - & - & [23] \\
\hline Multiple & MXL & 128 & 7.0 & 39.1 & 0.0 & 0.8 & [20] \\
\hline Countries & $\mathrm{CHB}$ & 206 & 0.0 & 24.8 & 0.5 & 0.0 & [20] \\
\hline$(1000$ & CEU & 198 & 1.5 & 5.6 & 0.0 & 4.6 & [20] \\
\hline Genomes) & ASW & 122 & 67.2 & 74.6 & 0.0 & 0.0 & [20] \\
\hline
\end{tabular}

Table 12. Comparison of CYP3A5 allele frequencies Indigenous North American populations to global populations from the 1000 Genomes Project [20]. $N$ represents the number of alleles. Global populations are abbreviated as follows: African Ancestry in Southwest US (ASW); Utah residents with Northern and Western European ancestry (CEU); Han Chinese in Beijing, China (CHB); Mexican Ancestry in Los Angeles, California (MXL).

\begin{tabular}{ccccccc}
\hline \multirow{2}{*}{ Country } & Population & $N$ & \multicolumn{3}{c}{ CYP3A5 MAF (\%) } \\
\cline { 4 - 6 } & & & $\begin{array}{c}* 3 \\
\text { rs776746 }\end{array}$ & $\begin{array}{c}{ }^{* 6} \\
\text { rs10264272 }\end{array}$ & $\begin{array}{c}\text { *7 } \\
\text { rs41303343 }\end{array}$ & \\
\hline USA & CSKT & 188 & 92.5 & 0.0 & 0.0 & {$[32]$} \\
\hline Multiple & MXL & 128 & 76.6 & 2.3 & 0.0 & {$[20]$} \\
Countries & CHB & 206 & 68.9 & 0.0 & 0.0 & {$[20]$} \\
$(1000$ & CEU & 198 & 96.0 & 0.0 & 0.0 & {$[20]$} \\
Genomes) & ASW & 122 & 31.2 & 4.9 & 12.3 & {$[20]$} \\
\hline
\end{tabular}

Reyes-Hernández et al. determined the MAFs of CYP3A4 variants in the Tepehuano and Mestizo populations and found that the frequencies were not significantly different between these two group [48]. The MAFs of CYP3A4*1B was $8.0 \%$ in Tepehuanos, compared to $8.8 \%$ in Mestizos and CYP $3 A 4^{*} 2$ was not detected in the Tepehuanos but was found at a low frequency of $0.5 \%$ in Mestizos (Table 11) [48]. CYP3A4*4, ${ }^{*} 5$ and ${ }^{*} 18$ were not found in either population [48]. Although the variant allele frequencies were similar between Tepehuanos and Mestizos for CYP3A4, it is important to consider that these populations may share similar allele frequencies in other $P 450$ 
genes. De Andrés et al. found that the CYP3A4*1B MAF was $4.8 \%$ in an Amerindian population including the Tarahumara, Tepehuano, Mexicanera, Huichol, Cora, Seri, Mayo and Guarijío groups (Table 11) [23]. The CYP3A4*1B allele did not significantly affect the parent to metabolite ratio of dextromethorphan to 3-methoxymorphinan [23], a CYP3A4 mediated pathway [163].

\subsection{CYP4F2}

CYP4F2 enzyme catabolizes vitamin $\mathrm{K}$ and, along with CYP2C9 and vitamin K oxidoreductase (VKOR), can affect the pharmacological response of warfarin, a VKOR antagonist. The Yup'ik AN population has a high frequency of CYP4F2*3 (Figure 13), which is a vitamin K sparing variant [164] and is associated with a higher warfarin dose requirement [165]. It is found at a frequency in the Yup'ik AN population higher than that seen elsewhere in the world, with one exception [166]. And is associated with a relatively high hepatic vitamin K status [33,167]. Selective pressure may have acted on the CYP4F2 gene in the Yup'ik population to conserve vitamin $\mathrm{K}$ due to the inconsistent access to tundra greens throughout the year $[33,167,168]$. The MAF of $C Y P 4 F 2 * 3$ is reported to be $50.9 \%$ and $31.5 \%$ in the Yup'ik and SCF populations, respectively (Table 13) [33]. While the contribution of the CYP4F2 variation to warfarin dose requirement is relatively low in European or African American populations, it may take on greater significance in AN populations due to the higher frequency of the CYP4F2*3 variant.

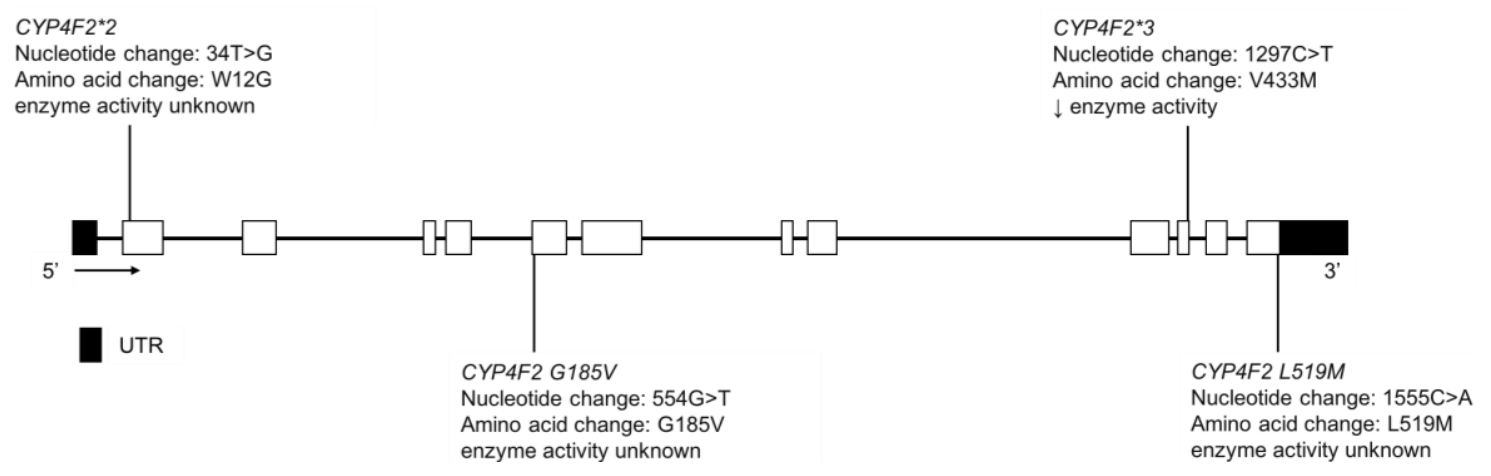

Figure 13. The human CYP4F2 gene and SNVs detected in the Yup'ik and SCF populations. Not shown is CYP4F2 spliceCG, a novel splice variant that changed the splice site of exon 1. Exon 1 is untranslated in CYP4F2. Open boxes represent exons, lines represent introns and shaded boxes represent UTR.

Table 13. Comparison of CYP4F2 allele frequencies Indigenous North American populations to global populations from the 1000 Genomes Project [20]. $N$ represents the number of alleles. Global populations are abbreviated as follows: African Ancestry in Southwest US (ASW); Utah residents with Northern and Western European ancestry (CEU); Han Chinese in Beijing, China (CHB); Mexican Ancestry in Los Angeles, California (MXL).

\begin{tabular}{|c|c|c|c|c|c|c|c|c|}
\hline \multirow{2}{*}{ Country } & \multirow{2}{*}{ Population } & \multirow{2}{*}{$N$} & \multicolumn{5}{|c|}{ CYP4F2 MAF (\%) } & \multirow{2}{*}{ Refs. } \\
\hline & & & $\begin{array}{c}* 2 \\
\text { rs3093105 }\end{array}$ & $\begin{array}{c}* 3 \\
\text { rs2108622 }\end{array}$ & $\begin{array}{c}G 185 V \\
\text { rs3093153 }\end{array}$ & $\begin{array}{c}L 519 M \\
\text { rs3093200 }\end{array}$ & $\begin{array}{c}\text { spliceCG } \\
\text { rsNA }\end{array}$ & \\
\hline \multirow{2}{*}{ USA } & Yup'ik & 700 & 3.7 & 50.9 & 0.3 & 0.0 & 0.7 & [33] \\
\hline & AIAN & 718 & 11.0 & 31.5 & 2.2 & 2.7 & 1.4 & [33] \\
\hline Multiple & MXL & 128 & 14.1 & 25.0 & 1.6 & 0.8 & - & [20] \\
\hline \multirow{2}{*}{$\begin{array}{c}\text { Countries } \\
(1000\end{array}$} & $\mathrm{CHB}$ & 206 & 8.3 & 21.8 & 0.0 & 0.0 & - & [20] \\
\hline & CEU & 198 & 14.1 & 24.8 & 7.0 & 8.6 & - & [20] \\
\hline Genomes) & ASW & 122 & 25.4 & 9.0 & 0.8 & 13.9 & - & [20] \\
\hline
\end{tabular}

Fohner et al. also reported the MAFs of CYP4F2*2, L519M, G185V and spliceCG in the Yup'ik population as $3.7 \%, 0.0 \%, 0.3 \%$ and $0.7 \%$, respectively, while in the AIAN cohort at SCF they were 
$11.0 \%, 2.7 \%, 2.2 \%$ and $1.4 \%$, respectively (Table 13 ) [33]. The functional impact of these variants is unclear but some may be deleterious.

\section{Discussion}

Pharmacogenetics is a growing field that presents the opportunity to improve safety and clinical outcomes of currently available treatments using individual genomic data. The implementation of this practice in all populations requires the elucidation and comprehensive understanding of genetic variation and its impact on drug phenotypes. In order to optimize clinical therapy and minimize adverse drug events in underserved Indigenous populations, these groups must be adequately represented in pharmacogenetic studies that identify genetic variation and inform on the dosing drugs that have established clinical associations with pharmacogene variation (e.g., abacavir, 6-mercaptopurine, warfarin, codeine), especially with narrow therapeutic index treatments.

Not only do Indigenous groups often have different allele frequencies compared to other global populations but marked differences in allele frequencies can also be found between subcultures within a given geographical region. Notable findings from the original studies highlighted in this review include the lower frequency of $C Y P 2 A 6$ loss-of-function alleles and a higher rate of nicotine metabolism in the NP AI, compared to a population of SW AI smokers [25]. With regards to CYP2C9, there was a lack of $C Y P 2 C 9 * 2$ in the Canadian Inuit population as well as many Amerindian groups including the Mexicanera, Huichol, Guarijío, Cora, Tarahumara and Purepecha [28,30,31]. CYP2C9*3 was also absent from the Canadian Inuit, Mexicanera, Seri, Purepecha and Huichol populations [28,30,31]. In contrast, $\mathrm{CYP} 2 \mathrm{C} 19^{*} 2$ was found at a high MAF in Tarahumaras, compared to other Indigenous peoples of Mexico [37]. The relatively high frequencies for CYP2D $6^{*} 4$ and CYP2D $6^{*} 41$ in the CSKT and AI youth may be important to consider with CYP2D6 substrates such as codeine, tamoxifen and antidepressants $[32,34]$. Conversely, certain subgroups in the Amerindian population (Tepehuano, Purepecha, Tojolabal, Tzotzil, Mexicanera, Cora and Guarijío) had a low proportion of CYP2D6 variants conferring PM status [37,41-43]. About $15 \%$ of the CSKT population would be expected to express CYP3A5, based on the CYP3A5*1 allele frequency [32]. In the Yup'ik AN population, the CYP4F2*3 variant is expressed at a frequency of $50.9 \%$, one of the highest MAFs seen across global populations for this SNV [33].

Indigenous populations of North America may also have novel P450 gene variation not seen in other populations of the world that can potentially influence drug phenotype. The allele frequencies of known and recently reported $C Y P 2 C 9$ variants in the AN Yup'ik population illustrate this scenario. The CYP2C9*2 and *3 alleles that define the CYP2C9 PM phenotype in the European population are found at very low frequencies in the Yup'ik population. The novel and relatively common $M 1 L$ and $N 218 I$ variants found in the Yup'ik population, in addition to CYP2C9*2 and *3 alleles, that are predicted to confer a CYP2C9 PM phenotype. Importantly, if only the allele frequencies known to be clinically relevant in the European population are applied to the Yup'ik population, an individual homozygous or heterozygous for the M1L or N218I variants would be classified as a CYP2C9 EM and improper warfarin dosing could result in adverse events for these individuals. This potential for misclassification and inappropriate drug dosing has also been described of African populations, where the $C Y P 2 C 9^{*} 8$ allele contributes to the PM phenotype [169]. This was also suggested by the work of de Andrés et al. where the CYP2C9, CYP2C19, or CYP2D6 phenotype for some Amerindians could not be accurately predicted based on genotype, possibly due to the presence of novel rare variation in these pharmacogenes [23].

Further studies are needed to identify and establish the allele frequencies of both known and novel variants in Indigenous populations, particularly in all P450 genes that encode enzymes that have a clinically significant impact on drug disposition. For example, despite the fact that CYP1A2 is a highly polymorphic enzyme important for the metabolism of many clinical drugs, no studies to date have assessed the frequencies of CYP1A2 allelic variants in Indigenous peoples of Canada or AIAN populations. Moving forward, it will also be important to improve genotyping and sequencing 
quality as well as increase study sample size, as these will help improve imputation and haplotype estimation in Indigenous populations, which may lead to the discovery of additional P450 SNVs or structural variants. Furthermore, there are problematic inconsistencies in population description for genetic studies, which is a recognized problem in the field [170]. In addition, the studies reported in this review do not fully capture the diversity of AI and other Indigenous tribes in North America. As seen in Figure 1, we found no studies from the US that were east of the Mississippi, leaving significant uncertainty about $\mathrm{P} 450$ genetic diversity for these people and drug phenotype relationships. In 2008, Jaja et al. conducted a systemic review of P450 variation in Indigenous and Native American Populations that identified ten original studies, of which six of were from Canada, four from North, Central and South America and none in AIAN [9]. This review identified twenty-seven original studies, with six in AIAN, seven in Indigenous people of Canada and fourteen in Amerindian populations of Mexico.

One method for increasing representation of Indigenous people in genetic studies is first to form collaborative research partnerships, in which community partners share control of the research process and apply the values and procedures of community-based participatory research to establish research priorities and acceptable conditions under which the research will occur [10]. We formed a research network involving three tribal organizations and three universities in 2010, to address the dearth of information about pharmacogenomics in AIAN populations. The research network built on several years of research and partnership development at three research sites. (1) Investigators at the Center for Alaska Native Health Research had established research partnerships with the Yukon-Kuskokwim Health Corporation, serving 23,000 Yup'ik people in southwestern Alaska and with several communities in the Yukon-Kuskokwim River Delta [171]. (2) SCF, a tribally owned and operated healthcare organization had established a Research Department and developed collaborative projects with investigators from the University of Washington. SCF is based in Anchorage and provides healthcare services to 65,000 AIAN customer-owners, serving about $55 \%$ of the total AN population in Alaska [171,172]. (3) Investigators at University of Montana had established partnerships with the CSKT of the Flathead Indian Reservation in northwestern Montana to pursue research with the Bitterroot Salish, Upper Pend d'Oreille and Kootenai tribes. There are $>7900$ enrolled CSKT members, with a large number of descendants $[171,173]$. These research partnerships provided the foundation for the Northwest-Alaska Pharmacogenomic Research Network, academic-tribal partnerships initiated with support from the National Institutes of Health. This review highlights findings of research derived from collaborations we have initiated, as well as additional relevant publications identified in the literature search.

The limited data on P450 genetic variation in Indigenous North American populations translates to missed opportunities for optimizing care. Interestingly, the data that does exist for Indigenous North American people suggests that they have unique genetic variation profiles that may critically impact their response to drug therapy. Without a complete understanding of this population's unique pharmacogene variation profile, Indigenous people may not derive the same benefit from genomics-based precision medicine as the European population. The populations included in pharmacogenetic research stand to gain the most from clinical trials findings that establish test validity and utility. A better understanding of the unique $P 450$ pharmacogenetic variation in Indigenous populations is needed if these communities are to be included in clinical decisions regarding personalized drug therapy and policies surrounding precision medicine.

Acknowledgments: This work was supported by T32 GM 007750, P01 GM116691, F32 GM119237, R01 HG009500. We would like to thank Allan Rettie for his thoughtful contributions.

Conflicts of Interest: The authors declare no conflict of interest. 


\section{References}

1. Relling, M.V.; Evans, W.E. Pharmacogenomics in the clinic. Nature 2015, 526, 343-350. [CrossRef] [PubMed]

2. Popejoy, A.B.; Fullerton, S.M. Genomics is failing on diversity. Nature 2016, 538, 161-164. [CrossRef] [PubMed]

3. Collins, F.S.; Varmus, H. A new initiative on precision medicine. N. Engl. J. Med. 2015, 372, 793-795. [CrossRef] [PubMed]

4. Aboriginal Peoples in Canada: First Nations People, Métis and Inuit, National Household Survey; Statistics Canada: Ottawa, QC, Canada, 2011.

5. Norris, T.; Vines, P.L.; Hoeffel, E.M. The American Indian and Alaska Native Population: 2010. In 2010 Census Briefs; U.S. Department of Commerce Economics and Statistics Administration U.S. CENSUS BUREAU: Suitland, MD, USA, 2012.

6. INEGI. Instituto Nacional de Estadística Geografía e Informática. Mexico. 2010. Available online: http:/ / www.inegi.gob.mx (accessed on 30 October 2017).

7. INALI. Instituto Nacional de Lenguas Indígenas. Mexico. 2008. Available online: http://www.inali.gob.mx (accessed on 30 October 2017).

8. Sosa-Macías, M.; Llerena, A. Cytochrome P450 genetic polymorphisms of Mexican indigenous populations. Drug Metabol. Drug Interact. 2013, 28, 193-208. [CrossRef] [PubMed]

9. Jaja, C.; Burke, W.; Thummel, K.; Edwards, K.; Veenstra, D.L. Cytochrome p450 enzyme polymorphism frequency in indigenous and Native American populations: A systematic review. Community Genet. 2008, 11, 141-149. [CrossRef] [PubMed]

10. Boyer, B.B.; Dillard, D.; Woodahl, E.L.; Whitener, R.; Thummel, K.E.; Burke, W. Ethical issues in developing pharmacogenetic research partnerships with American Indigenous communities. Clin. Pharmacol. Ther. 2011, 89, 343-345. [CrossRef] [PubMed]

11. Drabiak-Syed, K. Lessons from Havasupai Tribe v. Arizona State University Board of Regents: Recognizing group, cultural, and dignitary harms as legitimate risks warranting integration into research practice. J. Health Biomed. Law 2010, 6, 175-226.

12. Harmon, A. Indian Tribe Wins Fight to Limit Research of Its DNA, The New York Times: New York, NY, USA, 2010.

13. Foulks, E.F. Misalliances in the Barrow Alcohol Study. Am. Indian Alsk. Nativ. Ment. Health Res. 1989, 2, 7-17. [CrossRef]

14. Wiwchar, D. Nuu-Chah-Nulth Blood Returns to West Coast, Ha-Shilth-Sa: Port Alberni, BC, Canada, 2004.

15. Zanger, U.M.; Turpeinen, M.; Klein, K.; Schwab, M. Functional pharmacogenetics/genomics of human cytochromes P450 involved in drug biotransformation. Anal. Bioanal. Chem. 2008, 392, 1093-1108. [CrossRef] [PubMed]

16. Guengerich, F.P. Cytochrome p450 and chemical toxicology. Chem. Res. Toxicol. 2008, 21, 70-83. [CrossRef] [PubMed]

17. Zanger, U.M.; Schwab, M. Cytochrome P450 enzymes in drug metabolism: Regulation of gene expression, enzyme activities, and impact of genetic variation. Pharmacol. Ther. 2013, 138, 103-141. [CrossRef] [PubMed]

18. Wienkers, L.C.; Heath, T.G. Predicting in vivo drug interactions from in vitro drug discovery data. Nat. Rev. Drug Discov. 2005, 4, 825-833. [CrossRef] [PubMed]

19. Zhou, S.F.; Liu, J.P.; Chowbay, B. Polymorphism of human cytochrome P450 enzymes and its clinical impact. Drug Metab. Rev. 2009, 41, 89-295. [CrossRef] [PubMed]

20. Consortium, G.P.; Auton, A.; Brooks, L.D.; Durbin, R.M.; Garrison, E.P.; Kang, H.M.; Korbel, J.O.; Marchini, J.L.; McCarthy, S.; McVean, G.A.; et al. A global reference for human genetic variation. Nature 2015, 526, 68-74.

21. Zhou, Y.; Ingelman-Sundberg, M.; Lauschke, V.M. Worldwide Distribution of Cytochrome P450 Alleles: A Meta-analysis of Population-scale Sequencing Projects. Clin. Pharmacol. Ther. 2017, 102, 688-700. [CrossRef] [PubMed]

22. Fragoso, J.M.; Juárez-Cedillo, T.; Hernández-Pacheco, G.; Ramírez, E.; Zuñiga, J.; Izaguirre, R.; de la Peña, A.; Granados, J.; Vargas-Alarcón, G. Cytochrome P4501A1 polymorphisms in the Amerindian and Mestizo populations of Mexico. Cell Biochem. Funct. 2005, 23, 189-193. [CrossRef] [PubMed] 
23. De Andrés, F.; Sosa-Macías, M.; Ramos, B.P.L.; Naranjo, M.G.; LLerena, A. CYP450 Genotype/Phenotype Concordance in Mexican Amerindian Indigenous Populations-Where to from Here for Global Precision Medicine? OMICS 2017, 21, 509-519. [CrossRef] [PubMed]

24. Binnington, M.J.; Zhu, A.Z.; Renner, C.C.; Lanier, A.P.; Hatsukami, D.K.; Benowitz, N.L.; Tyndale, R.F. CYP2A6 and CYP2B6 genetic variation and its association with nicotine metabolism in South Western Alaska Native people. Pharmacogenet. Genom. 2012, 22, 429-440. [CrossRef] [PubMed]

25. Tanner, J.A.; Henderson, J.A.; Buchwald, D.; Howard, B.V.; Nez Henderson, P.; Tyndale, R.F. Variation in CYP2A6 and nicotine metabolism among two American Indian tribal groups differing in smoking patterns and risk for tobacco-related cancer. Pharmacogenet. Genom. 2017, 27, 169-178. [CrossRef] [PubMed]

26. Nowak, M.P.; Sellers, E.M.; Tyndale, R.F. Canadian Native Indians exhibit unique CYP2A6 and CYP2C19 Mutant allele frequencies. Clin. Pharmacol. Ther. 1998, 64, 378-383. [CrossRef]

27. Schoedel, K.A.; Hoffmann, E.B.; Rao, Y.; Sellers, E.M.; Tyndale, R.F. Ethnic variation in CYP2A6 and association of genetically slow nicotine metabolism and smoking in adult Caucasians. Pharmacogenetics 2004, 14, 615-626. [CrossRef] [PubMed]

28. Gaedigk, A.; Casley, W.L.; Tyndale, R.F.; Sellers, E.M.; Jurima-Romet, M.; Leeder, J.S. Cytochrome P4502C9 (CYP2C9) allele frequencies in Canadian Native Indian and Inuit populations. Can. J. Physiol. Pharmacol. 2001, 79, 841-847. [CrossRef] [PubMed]

29. Dorado, P.; Sosa-Macias, M.G.; Peñas-Lledó, E.M.; Alanis-Bañuelos, R.E.; Wong, M.L.; Licinio, J.; Lares-Asseff, I.; Llerena, A. CYP2C9 allele frequency differences between populations of Mexican-Mestizo, Mexican-Tepehuano, and Spaniards. Pharmacogenom. J. 2011, 11, 108-112. [CrossRef] [PubMed]

30. Sosa-Macías, M.; Lazalde-Ramos, B.P.; Galaviz-Hernández, C.; Rangel-Villalobos, H.; Salazar-Flores, J.; Martínez-Sevilla, V.M.; Martínez-Fierro, M.L.; Dorado, P.; Wong, M.L.; Licinio, J.; et al. Influence of admixture components on $C Y P 2 C 9 * 2$ allele frequency in eight indigenous populations from Northwest Mexico. Pharmacogenom. J. 2013, 13, 567-572. [CrossRef] [PubMed]

31. Castelán-Martínez, O.D.; Hoyo-Vadillo, C.; Sandoval-García, E.; Sandoval-Ramírez, L.; González-Ibarra, M.; Solano-Solano, G.; Gómez-Díaz, R.A.; Parra, E.J.; Cruz, M.; Valladares-Salgado, A. Allele frequency distribution of $C Y P 2 C 9 * 2$ and $C Y P 2 C 9 * 3$ polymorphisms in six Mexican populations. Gene 2013, 523, 167-172. [CrossRef] [PubMed]

32. Fohner, A.; Muzquiz, L.I.; Austin, M.A.; Gaedigk, A.; Gordon, A.; Thornton, T.; Rieder, M.J.; Pershouse, M.A.; Putnam, E.A.; Howlett, K.; et al. Pharmacogenetics in American Indian populations: Analysis of CYP2D6, CYP3A4, CYP3A5, and CYP2C9 in the Confederated Salish and Kootenai Tribes. Pharmacogenet. Genom. 2013, 23, 403-414. [CrossRef] [PubMed]

33. Fohner, A.E.; Robinson, R.; Yracheta, J.; Dillard, D.A.; Schilling, B.; Khan, B.; Hopkins, S.; Boyer, B.; Black, J.; Wiener, H.; et al. Variation in genes controlling warfarin disposition and response in American Indian and Alaska Native people: CYP2C9, VKORC1, CYP4F2, CYP4F11, GGCX. Pharmacogenet. Genom. 2015, 25, 343-353. [CrossRef] [PubMed]

34. McGrane, I.R.; Loveland, J.G. Pharmacogenetics of Cytochrome P450 Enzymes in American Indian and Caucasian Children Admitted to a Psychiatric Hospital. J. Child Adolesc. Psychopharmacol. 2016, 26, 395-399. [CrossRef] [PubMed]

35. Jurima-Romet, M.; Goldstein, J.A.; LeBelle, M.; Aubin, R.A.; Foster, B.C.; Walop, W.; Rode, A. CYP2C19 genotyping and associated mephenytoin hydroxylation polymorphism in a Canadian Inuit population. Pharmacogenetics 1996, 6, 329-339. [CrossRef] [PubMed]

36. Oestreich, J.H.; Best, L.G.; Dobesh, P.P. Prevalence of CYP2C19 variant alleles and pharmacodynamic variability of aspirin and clopidogrel in Native Americans. Am. Heart J. 2014, 167, 413-418. [CrossRef] [PubMed]

37. Salazar-Flores, J.; Torres-Reyes, L.A.; Martínez-Cortés, G.; Rubi-Castellanos, R.; Sosa-Macías, M.; Muñoz-Valle, J.F.; González-González, C.; Ramírez, A.; Román, R.; Méndez, J.L.; et al. Distribution of CYP2D6 and CYP2C19 polymorphisms associated with poor metabolizer phenotype in five Amerindian groups and western Mestizos from Mexico. Genet. Test. Mol. Biomark. 2012, 16, 1098-1104. [CrossRef] [PubMed]

38. Jurima-Romet, M.; Foster, B.C.; Casley, W.L.; Rode, A.; Vloshinsky, P.; Huang, H.S.; Geertsen, S. CYP2D6-related oxidation polymorphism in a Canadian Inuit population. Can. J. Physiol. Pharmacol. 1997, 75, 165-172. [CrossRef] [PubMed] 
39. Nowak, M.P.; Tyndale, R.F.; Sellers, E.M. CYP2D6 phenotype and genotype in a Canadian Native Indian population. Pharmacogenetics 1997, 7, 145-148. [CrossRef] [PubMed]

40. Lares-Asseff, I.; Sosa-Macías, M.; Elizondo-Azuela, G.; Flores-Pérez, C.; Flores-Pérez, J.; Bradley-Alvarez, F. Phenotypical expression of CYP2D6 in Amerindians of Tepehuano origin from Durango, Mexico. Proc. West. Pharmacol. Soc. 2005, 48, 102-107. [PubMed]

41. Sosa-Macías, M.; Elizondo, G.; Flores-Pérez, C.; Flores-Pérez, J.; Bradley-Alvarez, F.; Alanis-Bañuelos, R.E.; Lares-Asseff, I. CYP2D6 genotype and phenotype in Amerindians of Tepehuano origin and Mestizos of Durango, Mexico. J. Clin. Pharmacol. 2006, 46, 527-536. [CrossRef] [PubMed]

42. Sosa-Macías, M.; Dorado, P.; Alanis-Bañuelos, R.E.; Llerena, A.; Lares-Asseff, I. Influence of CYP2D6 deletion, multiplication, $-1584 \mathrm{C}->\mathrm{G}, 31 \mathrm{G}->\mathrm{A}$ and 2988G->A gene polymorphisms on dextromethorphan metabolism among Mexican Tepehuanos and mestizos. Pharmacology 2010, 86, 30-36. [CrossRef] [PubMed]

43. Lazalde-Ramos, B.P.; Martínez-Fierro, M.L.; Galaviz-Hernández, C.; Garza-Veloz, I.; Naranjo, M.E.; Sosa-Macías, M.; Llerena, A. CYP2D6 gene polymorphisms and predicted phenotypes in eight indigenous groups from Northwestern Mexico. Pharmacogenomics 2014, 15, 339-348. [CrossRef] [PubMed]

44. López-López, M.; Peñas-Lledó, E.; Dorado, P.; Ortega, A.; Corona, T.; Ochoa, A.; Yescas, P.; Alonso, E.; LLerena, A. CYP2D6 genetic polymorphisms in Southern Mexican Mayan Lacandones and Mestizos from Chiapas. Pharmacogenomics 2014, 15, 1859-1865. [CrossRef] [PubMed]

45. Perez-Paramo, Y.X.; Hernandez-Cabrera, F.; Dorado, P.; Llerena, A.; Muñoz-Jimenez, S.; Ortiz-Lopez, R.; Rojas-Martinez, A. Interethnic relationships of CYP2D6 variants in Native and Mestizo populations sharing the same ecosystem. Pharmacogenomics 2015, 16, 703-712. [CrossRef] [PubMed]

46. Howard, L.A.; Ahluwalia, J.S.; Lin, S.K.; Sellers, E.M.; Tyndale, R.F. CYP2E1*1D regulatory polymorphism: Association with alcohol and nicotine dependence. Pharmacogenetics 2003, 13, 321-328. [CrossRef] [PubMed]

47. Gordillo-Bastidas, E.; Panduro, A.; Gordillo-Bastidas, D.; Zepeda-Carrillo, E.A.; García-Bañuelos, J.J.; Muñoz-Valle, J.F.; Bastidas-Ramírez, B.E. Polymorphisms of alcohol metabolizing enzymes in indigenous Mexican population: Unusual high frequency of CYP2E1*C2 allele. Alcohol. Clin. Exp. Res. 2010, 34, 142-149. [CrossRef] [PubMed]

48. Reyes-Hernández, O.D.; Lares-Asseff, I.; Sosa-Macias, M.; Vega, L.; Albores, A.; Elizondo, G. A comparative study of CYP3A4 polymorphisms in Mexican Amerindian and Mestizo populations. Pharmacology 2008, 81, 97-103. [CrossRef] [PubMed]

49. Eugster, H.P.; Probst, M.; Würgler, F.E.; Sengstag, C. Caffeine, estradiol, and progesterone interact with human CYP1A1 and CYP1A2. Evidence from cDNA-directed expression in Saccharomyces cerevisiae. Drug Metab. Dispos. 1993, 21, 43-49. [PubMed]

50. Indulski, J.A.; Lutz, W. Metabolic genotype in relation to individual susceptibility to environmental carcinogens. Int. Arch. Occup. Environ. Health 2000, 73, 71-85. [CrossRef] [PubMed]

51. Spurr, N.K.; Gough, A.C.; Stevenson, K.; Wolf, C.R. Msp-1 polymorphism detected with a cDNA probe for the P-450 I family on chromosome 15. Nucleic Acids Res. 1987, 15, 5901. [CrossRef] [PubMed]

52. Cosma, G.; Crofts, F.; Taioli, E.; Toniolo, P.; Garte, S. Relationship between genotype and function of the human CYP1A1 gene. J. Toxicol. Environ. Health 1993, 40, 309-316. [CrossRef] [PubMed]

53. Crofts, F.; Taioli, E.; Trachman, J.; Cosma, G.N.; Currie, D.; Toniolo, P.; Garte, S.J. Functional significance of different human CYP1A1 genotypes. Carcinogenesis 1994, 15, 2961-2963. [CrossRef] [PubMed]

54. Bertilsson, L.; Carrillo, J.A.; Dahl, M.L.; Llerena, A.; Alm, C.; Bondesson, U.; Lindström, L.; Rodriguez de la Rubia, I.; Ramos, S.; Benitez, J. Clozapine disposition covaries with CYP1A2 activity determined by a caffeine test. Br. J. Clin. Pharmacol. 1994, 38, 471-473. [CrossRef] [PubMed]

55. Störmer, E.; von Moltke, L.L.; Shader, R.I.; Greenblatt, D.J. Metabolism of the antidepressant mirtazapine in vitro: Contribution of cytochromes P-450 1A2, 2D6, and 3A4. Drug Metab. Dispos. 2000, 28, 1168-1175. [PubMed]

56. Ha, H.R.; Chen, J.; Freiburghaus, A.U.; Follath, F. Metabolism of theophylline by cDNA-expressed human cytochromes P-450. Br. J. Clin. Pharmacol. 1995, 39, 321-326. [CrossRef] [PubMed]

57. Granfors, M.T.; Backman, J.T.; Laitila, J.; Neuvonen, P.J. Tizanidine is mainly metabolized by cytochrome p450 1A2 in vitro. Br. J. Clin. Pharmacol. 2004, 57, 349-353. [CrossRef] [PubMed]

58. Fuhr, U.; Kober, S.; Zaigler, M.; Mutschler, E.; Spahn-Langguth, H. Rate-limiting biotransformation of triamterene is mediated by CYP1A2. Int. J. Clin. Pharmacol. Ther. 2005, 43, 327-334. [CrossRef] [PubMed] 
59. Djordjevic, N.; Ghotbi, R.; Bertilsson, L.; Jankovic, S.; Aklillu, E. Induction of CYP1A2 by heavy coffee consumption in Serbs and Swedes. Eur. J. Clin. Pharmacol. 2008, 64, 381-385. [CrossRef] [PubMed]

60. Ghotbi, R.; Christensen, M.; Roh, H.K.; Ingelman-Sundberg, M.; Aklillu, E.; Bertilsson, L. Comparisons of CYP1A2 genetic polymorphisms, enzyme activity and the genotype-phenotype relationship in Swedes and Koreans. Eur. J. Clin. Pharmacol. 2007, 63, 537-546. [CrossRef] [PubMed]

61. Djordjevic, N.; Ghotbi, R.; Jankovic, S.; Aklillu, E. Induction of CYP1A2 by heavy coffee consumption is associated with the CYP1A2 -163C>A polymorphism. Eur. J. Clin. Pharmacol. 2010, 66, 697-703. [CrossRef] [PubMed]

62. Hukkanen, J.; Jacob, P.; Benowitz, N.L. Metabolism and disposition kinetics of nicotine. Pharmacol. Rev. 2005, 57, 79-115. [CrossRef] [PubMed]

63. Komatsu, T.; Yamazaki, H.; Shimada, N.; Nakajima, M.; Yokoi, T. Roles of cytochromes P450 1A2, 2A6, and 2C8 in 5-fluorouracil formation from Tegafur, an anticancer prodrug, in human liver microsomes. Drug Metab. Dispos. 2000, 28, 1457-1463. [PubMed]

64. Kiang, T.K.; Ho, P.C.; Anari, M.R.; Tong, V.; Abbott, F.S.; Chang, T.K. Contribution of CYP2C9, CYP2A6, and CYP2B6 to Valproic acid metabolism in hepatic Microsomes from individuals with the CYP2C ${ }^{*} 1{ }^{*} 1$ genotype. Toxicol. Sci. 2006, 94, 261-271. [CrossRef] [PubMed]

65. Tan, L.; Yu, J.T.; Sun, Y.P.; Ou, J.R.; Song, J.H.; Yu, Y. The influence of cytochrome oxidase CYP2A6, CYP2B6, and CYP2C9 polymorphisms on the plasma concentrations of Valproic acid in epileptic patients. Clin. Neurol. Neurosurg. 2010, 112, 320-323. [CrossRef] [PubMed]

66. Miles, J.S.; McLaren, A.W.; Forrester, L.M.; Glancey, M.J.; Lang, M.A.; Wolf, C.R. Identification of the human liver cytochrome P-450 responsible for Coumarin 7-hydroxylase activity. Biochem. J. 1990, 267, 365-371. [CrossRef] [PubMed]

67. Sellers, E.M.; Ramamoorthy, Y.; Zeman, M.V.; Djordjevic, M.V.; Tyndale, R.F. The effect of methoxsalen on nicotine and 4-(methylnitrosamino)-1-(3-pyridyl)-1-butanone (NNK) metabolism in vivo. Nicot. Tob. Res. 2003, 5, 891-899. [CrossRef] [PubMed]

68. Fujita, K.; Kamataki, T. Predicting the mutagenicity of tobacco-related $N$-nitrosamines in humans using 11 strains of Salmonella typhimurium YG7108, each coexpressing a form of human cytochrome P450 along with NADPH-cytochrome P450 reductase. Environ. Mol. Mutagen. 2001, 38, 339-346. [CrossRef] [PubMed]

69. Ray, R.; Tyndale, R.F.; Lerman, C. Nicotine dependence pharmacogenetics: Role of genetic variation in nicotine-metabolizing enzymes. J. Neurogenet. 2009, 23, 252-261. [CrossRef] [PubMed]

70. Benowitz, N.L.; Swan, G.E.; Jacob, P.; Lessov-Schlaggar, C.N.; Tyndale, R.F. CYP2A6 genotype and the metabolism and disposition kinetics of nicotine. Clin. Pharmacol. Ther. 2006, 80, 457-467. [CrossRef] [PubMed]

71. Nakajima, M.; Yamamoto, T.; Nunoya, K.; Yokoi, T.; Nagashima, K.; Inoue, K.; Funae, Y.; Shimada, N.; Kamataki, T.; Kuroiwa, Y. Characterization of CYP2A6 involved in $3^{\prime}$-hydroxylation of cotinine in human liver microsomes. J. Pharmacol. Exp. Ther. 1996, 277, 1010-1015. [PubMed]

72. Dempsey, D.; Tutka, P.; Jacob, P.; Allen, F.; Schoedel, K.; Tyndale, R.F.; Benowitz, N.L. Nicotine metabolite ratio as an index of cytochrome P450 2A6 metabolic activity. Clin. Pharmacol. Ther. 2004, 76, 64-72. [CrossRef] [PubMed]

73. Tanner, J.A.; Chenoweth, M.J.; Tyndale, R.F. Pharmacogenetics of nicotine and associated smoking behaviors. Curr. Top. Behav. Neurosci. 2015, 23, 37-86. [PubMed]

74. Lerman, C.; Tyndale, R.; Patterson, F.; Wileyto, E.P.; Shields, P.G.; Pinto, A.; Benowitz, N. Nicotine metabolite ratio predicts efficacy of transdermal nicotine for smoking cessation. Clin. Pharmacol. Ther. 2006, 79, 600-608. [CrossRef] [PubMed]

75. Schnoll, R.A.; Patterson, F.; Wileyto, E.P.; Tyndale, R.F.; Benowitz, N.; Lerman, C. Nicotine metabolic rate predicts successful smoking cessation with transdermal nicotine: A validation study. Pharmacol. Biochem. Behav. 2009, 92, 6-11. [CrossRef] [PubMed]

76. Lerman, C.; Jepson, C.; Wileyto, E.P.; Patterson, F.; Schnoll, R.; Mroziewicz, M.; Benowitz, N.; Tyndale, R.F. Genetic variation in nicotine metabolism predicts the efficacy of extended-duration transdermal nicotine therapy. Clin. Pharmacol. Ther. 2010, 87, 553-557. [CrossRef] [PubMed]

77. Lerman, C.; Schnoll, R.A.; Hawk, L.W.; Cinciripini, P.; George, T.P.; Wileyto, E.P.; Swan, G.E.; Benowitz, N.L.; Heitjan, D.F.; Tyndale, R.F.; et al. Use of the nicotine metabolite ratio as a genetically informed 
biomarker of response to nicotine patch or varenicline for smoking cessation: A randomised, double-blind placebo-controlled trial. Lancet Respir. Med. 2015, 3, 131-138. [CrossRef]

78. Chenoweth, M.J.; Tyndale, R.F. Pharmacogenetic Optimization of Smoking Cessation Treatment. Trends Pharmacol. Sci. 2017, 38, 55-66. [CrossRef] [PubMed]

79. Wassenaar, C.A.; Dong, Q.; Wei, Q.; Amos, C.I.; Spitz, M.R.; Tyndale, R.F. Relationship between CYP2A6 and CHRNA5-CHRNA3-CHRNB4 variation and smoking behaviors and lung cancer risk. J. Natl. Cancer Inst. 2011, 103, 1342-1346. [CrossRef] [PubMed]

80. Lek, M.; Karczewski, K.J.; Minikel, E.V.; Samocha, K.E.; Banks, E.; Fennell, T.; O’Donnell-Luria, A.H.; Ware, J.S.; Hill, A.J.; Cummings, B.B.; et al. Analysis of protein-coding genetic variation in 60,706 humans. Nature 2016, 536, 285-291. [CrossRef] [PubMed]

81. Machiela, M.J.; Chanock, S.J. LDlink: A web-based application for exploring population-specific haplotype structure and linking correlated alleles of possible functional variants. Bioinformatics 2015, 31, 3555-3557. [CrossRef] [PubMed]

82. Faucette, S.R.; Hawke, R.L.; Lecluyse, E.L.; Shord, S.S.; Yan, B.; Laethem, R.M.; Lindley, C.M. Validation of bupropion hydroxylation as a selective marker of human cytochrome P450 2B6 catalytic activity. Drug Metab. Dispos. 2000, 28, 1222-1230. [PubMed]

83. Hesse, L.M.; He, P.; Krishnaswamy, S.; Hao, Q.; Hogan, K.; von Moltke, L.L.; Greenblatt, D.J.; Court, M.H. Pharmacogenetic determinants of Interindividual variability in bupropion hydroxylation by cytochrome P450 2B6 in human liver microsomes. Pharmacogenetics 2004, 14, 225-238. [CrossRef] [PubMed]

84. Chang, T.K.; Weber, G.F.; Crespi, C.L.; Waxman, D.J. Differential activation of cyclophosphamide and inofosphamide by cytochromes P-450 2B and 3A in human liver microsomes. Cancer Res. 1993, 53, 5629-5637. [PubMed]

85. Ward, B.A.; Gorski, J.C.; Jones, D.R.; Hall, S.D.; Flockhart, D.A.; Desta, Z. The cytochrome P450 2B6 (CYP2B6) is the main catalyst of efavirenz primary and secondary metabolism: Implication for HIV/AIDS therapy and utility of Efavirenz as a substrate marker of CYP2B6 catalytic activity. J. Pharmacol. Exp. Ther. 2003, 306, 287-300. [CrossRef] [PubMed]

86. Hijazi, Y.; Boulieu, R. Contribution of CYP3A4, CYP2B6, and CYP2C9 isoforms to N-demethylation of ketamine in human liver microsomes. Drug Metab. Dispos. 2002, 30, 853-858. [CrossRef] [PubMed]

87. Yanagihara, Y.; Kariya, S.; Ohtani, M.; Uchino, K.; Aoyama, T.; Yamamura, Y.; Iga, T. Involvement of CYP2B6 in n-demethylation of ketamine in human liver microsomes. Drug Metab. Dispos. 2001, 29, 887-890. [PubMed]

88. Totah, R.A.; Sheffels, P.; Roberts, T.; Whittington, D.; Thummel, K.; Kharasch, E.D. Role of CYP2B6 in stereoselective human methadone metabolism. Anesthesiology 2008, 108, 363-374. [CrossRef] [PubMed]

89. Yamanaka, H.; Nakajima, M.; Nishimura, K.; Yoshida, R.; Fukami, T.; Katoh, M.; Yokoi, T. Metabolic profile of nicotine in subjects whose CYP2A6 gene is deleted. Eur. J. Pharm. Sci. 2004, 22, 419-425. [CrossRef] [PubMed]

90. Ray, R.; Schnoll, R.A.; Lerman, C. Nicotine dependence: Biology, behavior, and treatment. Annu. Rev. Med. 2009, 60, 247-260. [CrossRef] [PubMed]

91. Johnstone, E.; Benowitz, N.; Cargill, A.; Jacob, R.; Hinks, L.; Day, I.; Murphy, M.; Walton, R. Determinants of the rate of nicotine metabolism and effects on smoking behavior. Clin. Pharmacol. Ther. 2006, 80, 319-330. [CrossRef] [PubMed]

92. Haberl, M.; Anwald, B.; Klein, K.; Weil, R.; Fuss, C.; Gepdiremen, A.; Zanger, U.M.; Meyer, U.A.; Wojnowski, L. Three haplotypes associated with CYP2A6 phenotypes in Caucasians. Pharmacogenet. Genom. 2005, 15, 609-624. [CrossRef]

93. Miners, J.O.; Birkett, D.J. Cytochrome P4502C9: An enzyme of major importance in human drug metabolism. Br. J. Clin. Pharmacol. 1998, 45, 525-538. [CrossRef] [PubMed]

94. Yamazaki, H.; Inoue, K.; Chiba, K.; Ozawa, N.; Kawai, T.; Suzuki, Y.; Goldstein, J.A.; Guengerich, F.P.; Shimada, T. Comparative studies on the catalytic roles of cytochrome P450 2C9 and its Cys- and Leu-variants in the oxidation of warfarin, flurbiprofen, and diclofenac by human liver microsomes. Biochem. Pharmacol. 1998, 56, 243-251. [CrossRef]

95. Tracy, T.S.; Rosenbluth, B.W.; Wrighton, S.A.; Gonzalez, F.J.; Korzekwa, K.R. Role of cytochrome P450 2 C9 and an allelic variant in the $4^{\prime}$-hydroxylation of $(R)$ - and (S)-flurbiprofen. Biochem. Pharmacol. 1995, 49, 1269-1275. [CrossRef] 
96. Hamman, M.A.; Thompson, G.A.; Hall, S.D. Regioselective and stereoselective metabolism of ibuprofen by human cytochrome P450 2C. Biochem. Pharmacol. 1997, 54, 33-41. [CrossRef]

97. Miners, J.O.; Coulter, S.; Tukey, R.H.; Veronese, M.E.; Birkett, D.J. Cytochromes P450, 1A2, and 2C9 are responsible for the human hepatic O-demethylation of $R$ - and S-naproxen. Biochem. Pharmacol. 1996, 51, 1003-1008. [CrossRef]

98. Stearns, R.A.; Chakravarty, P.K.; Chen, R.; Chiu, S.H. Biotransformation of losartan to its active carboxylic acid metabolite in human liver microsomes. Role of cytochrome P4502C and 3A subfamily members. Drug Metab. Dispos. 1995, 23, 207-215. [PubMed]

99. Rettie, A.E.; Korzekwa, K.R.; Kunze, K.L.; Lawrence, R.F.; Eddy, A.C.; Aoyama, T.; Gelboin, H.V.; Gonzalez, F.J; Trager, W.F. Hydroxylation of warfarin by human cDNA-expressed cytochrome P-450: A role for P-4502C9 in the etiology of (S)-warfarin-drug interactions. Chem. Res. Toxicol. 1992, 5, 54-59. [CrossRef] [PubMed]

100. Miners, J.O.; Birkett, D.J. Use of tolbutamide as a substrate probe for human hepatic cytochrome P450 2 C9. Methods Enzymol. 1996, 272, 139-145. [PubMed]

101. Giancarlo, G.M.; Venkatakrishnan, K.; Granda, B.W.; von Moltke, L.L.; Greenblatt, D.J. Relative contributions of CYP2C9 and 2C19 to phenytoin 4-hydroxylation in vitro: Inhibition by sulfaphenazole, omeprazole, and ticlopidine. Eur. J. Clin. Pharmacol. 2001, 57, 31-36. [CrossRef] [PubMed]

102. Schilling, B. Anticoagulation Care for Alaska Native Customer-Owners within the Nuka Model of Care, 7th ed.; Dawn AC Anticoagulation Management Software North American User Group Meeting: La Jolla, CA, USA, 2013.

103. Johnson, J.A.; Caudle, K.E.; Gong, L.; Whirl-Carrillo, M.; Stein, C.M.; Scott, S.A.; Lee, M.T.; Gage, B.F.; Kimmel, S.E.; Perera, M.A.; et al. Clinical Pharmacogenetics Implementation Consortium (CPIC) guideline for pharmacogenetics-guided warfarin dosing: 2017 Update. Clin. Pharmacol. Ther. 2017, 102, 397-404. [CrossRef] [PubMed]

104. Anderson, J.L.; Horne, B.D.; Stevens, S.M.; Grove, A.S.; Barton, S.; Nicholas, Z.P.; Kahn, S.F.; May, H.T.; Samuelson, K.M.; Muhlestein, J.B.; et al. Randomized trial of genotype-guided versus standard warfarin dosing in patients initiating oral anticoagulation. Circulation 2007, 116, 2563-2570. [CrossRef] [PubMed]

105. Starita, L.M.; Ahituv, N.; Dunham, M.J.; Kitzman, J.O.; Roth, F.P.; Seelig, G.; Shendure, J.; Fowler, D.M. Variant interpretation: Functional assays to the rescue. Am. J. Hum. Genet. 2017, 101, 315-325. [CrossRef] [PubMed]

106. Kazui, M.; Nishiya, Y.; Ishizuka, T.; Hagihara, K.; Farid, N.A.; Okazaki, O.; Ikeda, T.; Kurihara, A. Identification of the human cytochrome P450 enzymes involved in the two oxidative steps in the bioactivation of clopidogrel to its pharmacologically active metabolite. Drug Metab. Dispos. 2010, 38, 92-99. [CrossRef] [PubMed]

107. Andersson, T.; Regårdh, C.G.; Dahl-Puustinen, M.L.; Bertilsson, L. Slow omeprazole metabolizers are also poor S-mephenytoin hydroxylators. Ther. Drug Monit. 1990, 12, 415-416. [CrossRef] [PubMed]

108. Olesen, O.V.; Linnet, K. Metabolism of the tricyclic antidepressant amitriptyline by cDNA-expressed human cytochrome P450 enzymes. Pharmacology 1997, 55, 235-243. [CrossRef] [PubMed]

109. Skjelbo, E.; Brøsen, K.; Hallas, J.; Gram, L.F. The mephenytoin oxidation polymorphism is partially responsible for the $\mathrm{N}$-demethylation of imipramine. Clin. Pharmacol. Ther. 1991, 49, 18-23. [CrossRef] [PubMed]

110. Kobayashi, K.; Chiba, K.; Yagi, T.; Shimada, N.; Taniguchi, T.; Horie, T.; Tani, M.; Yamamoto, T.; Ishizaki, T.; Kuroiwa, Y. Identification of cytochrome P450 isoforms involved in citalopram $N$-demethylation by human liver microsomes. J. Pharmacol. Exp. Ther. 1997, 280, 927-933. [PubMed]

111. Olesen, O.V.; Linnet, K. Studies on the stereoselective metabolism of citalopram by human liver microsomes and cDNA-expressed cytochrome P450 enzymes. Pharmacology 1999, 59, 298-309. [CrossRef] [PubMed]

112. von Moltke, L.L.; Greenblatt, D.J.; Duan, S.X.; Schmider, J.; Wright, C.E.; Harmatz, J.S.; Shader, R.I. Human cytochromes mediating $N$-demethylation of fluoxetine in vitro. Psychopharmacology 1997, 132, $402-407$. [CrossRef] [PubMed]

113. Xu, Z.H.; Wang, W.; Zhao, X.J.; Huang, S.L.; Zhu, B.; He, N.; Shu, Y.; Liu, Z.Q.; Zhou, H.H. Evidence for involvement of polymorphic CYP2C19 and 2C9 in the $N$-demethylation of sertraline in human liver microsomes. Br. J. Clin. Pharmacol. 1999, 48, 416-423. [CrossRef] [PubMed]

114. Andersson, T.; Miners, J.O.; Veronese, M.E.; Birkett, D.J. Diazepam metabolism by human liver microsomes is mediated by both S-mephenytoin hydroxylase and CYP3A isoforms. Br. J. Clin. Pharmacol. 1994, 38, 131-137. [CrossRef] [PubMed] 
115. Sim, S.C.; Risinger, C.; Dahl, M.L.; Aklillu, E.; Christensen, M.; Bertilsson, L.; Ingelman-Sundberg, M. A common novel CYP2C19 gene variant causes ultrarapid drug metabolism relevant for the drug response to proton pump inhibitors and antidepressants. Clin. Pharmacol. Ther. 2006, 79, 103-113. [CrossRef] [PubMed]

116. Goldstein, J.A.; Faletto, M.B.; Romkes-Sparks, M.; Sullivan, T.; Kitareewan, S.; Raucy, J.L.; Lasker, J.M.; Ghanayem, B.I. Evidence that CYP2C19 is the major (S)-mephenytoin $4^{\prime}$-hydroxylase in humans. Biochemistry 1994, 33, 1743-1752. [CrossRef] [PubMed]

117. Wrighton, S.A.; Stevens, J.C.; Becker, G.W.; VandenBranden, M. Isolation and characterization of human liver cytochrome P450 2C19: Correlation between 2C19 and S-mephenytoin 4'-hydroxylation. Arch. Biochem. Biophys. 1993, 306, 240-245. [CrossRef] [PubMed]

118. Goldstein, J.A.; de Morais, S.M. Biochemistry and molecular biology of the human CYP2C subfamily. Pharmacogenetics 1994, 4, 285-299. [CrossRef] [PubMed]

119. Wedlund, P.J.; Aslanian, W.S.; McAllister, C.B.; Wilkinson, G.R.; Branch, R.A. Mephenytoin hydroxylation deficiency in Caucasians: Frequency of a new oxidative drug metabolism polymorphism. Clin. Pharmacol. Ther. 1984, 36, 773-780. [CrossRef] [PubMed]

120. Dahl, M.L.; Gunes, A. Implications of Inter-Individual Differences in Clopidogrel Metabolism, with Focus on Pharmacogenetics. Pharmaceuticals 2010, 3, 782-794. [CrossRef] [PubMed]

121. Poulsen, L.; Brøsen, K.; Arendt-Nielsen, L.; Gram, L.F.; Elbaek, K.; Sindrup, S.H. Codeine and morphine in extensive and poor metabolizers of sparteine: Pharmacokinetics, analgesic effect and side effects. Eur. J. Clin. Pharmacol. 1996, 51, 289-295. [CrossRef] [PubMed]

122. Otton, S.V.; Schadel, M.; Cheung, S.W.; Kaplan, H.L.; Busto, U.E.; Sellers, E.M. CYP2D6 phenotype determines the metabolic conversion of hydrocodone to hydromorphone. Clin. Pharmacol. Ther. 1993, 54, 463-472. [CrossRef] [PubMed]

123. Olesen, O.V.; Linnet, K. Hydroxylation and demethylation of the tricyclic antidepressant nortriptyline by cDNA-expressed human cytochrome P-450 isozymes. Drug Metab. Dispos. 1997, 25, 740-744. [PubMed]

124. Fogelman, S.M.; Schmider, J.; Venkatakrishnan, K.; von Moltke, L.L.; Harmatz, J.S.; Shader, R.I.; Greenblatt, D.J. $\mathrm{O}$ - and $\mathrm{N}$-demethylation of venlafaxine in vitro by human liver microsomes and by microsomes from cDNA-transfected cells: Effect of metabolic inhibitors and SSRI antidepressants. Neuropsychopharmacology 1999, 20, 480-490. [CrossRef]

125. Yasui-Furukori, N.; Hidestrand, M.; Spina, E.; Facciolá, G.; Scordo, M.G.; Tybring, G. Different enantioselective 9-hydroxylation of risperidone by the two human CYP2D6 and CYP3A4 enzymes. Drug Metab. Dispos. 2001, 29, 1263-1268. [PubMed]

126. Muralidharan, G.; Cooper, J.K.; Hawes, E.M.; Korchinski, E.D.; Midha, K.K. Quinidine inhibits the 7-hydroxylation of chlorpromazine in extensive metabolisers of debrisoquine. Eur. J. Clin. Pharmacol. 1996, 50, 121-128. [CrossRef] [PubMed]

127. Lennard, M.S.; Silas, J.H.; Freestone, S.; Trevethick, J. Defective metabolism of metoprolol in poor hydroxylators of debrisoquine. Br. J. Clin. Pharmacol. 1982, 14, 301-303. [CrossRef] [PubMed]

128. Ward, S.A.; Walle, T.; Walle, U.K.; Wilkinson, G.R.; Branch, R.A. Propranolol's metabolism is determined by both mephenytoin and debrisoquin hydroxylase activities. Clin. Pharmacol. Ther. 1989, 45, 72-79. [CrossRef] [PubMed]

129. Oldham, H.G.; Clarke, S.E. In vitro identification of the human cytochrome P450 enzymes involved in the metabolism of $R(+)$ - and S(-)-carvedilol. Drug Metab. Dispos. 1997, 25, 970-977. [PubMed]

130. Gasche, Y.; Daali, Y.; Fathi, M.; Chiappe, A.; Cottini, S.; Dayer, P.; Desmeules, J. Codeine intoxication associated with ultrarapid CYP2D6 metabolism. N. Engl. J. Med. 2004, 351, 2827-2831. [CrossRef] [PubMed]

131. Kelly, L.E.; Rieder, M.; van den Anker, J.; Malkin, B.; Ross, C.; Neely, M.N.; Carleton, B.; Hayden, M.R.; Madadi, P.; Koren, G. More codeine fatalities after tonsillectomy in North American children. Pediatrics 2012, 129, e1343-e1347. [CrossRef] [PubMed]

132. Schmid, B.; Bircher, J.; Preisig, R.; Küpfer, A. Polymorphic dextromethorphan metabolism: Co-segregation of oxidative O-demethylation with debrisoquin hydroxylation. Clin. Pharmacol. Ther. 1985, 38, 618-624. [CrossRef] [PubMed]

133. Küpfer, A.; Schmid, B.; Pfaff, G. Pharmacogenetics of dextromethorphan O-demethylation in man. Xenobiotica 1986, 16, 421-433. [CrossRef] [PubMed] 
134. Broly, F.; Gaedigk, A.; Heim, M.; Eichelbaum, M.; Morike, K.; Meyer, U.A. Debrisoquine/sparteine hydroxylation genotype and phenotype: Analysis of common mutations and alleles of CYP2D6 in a European population. DNA Cell Biol. 1991, 10, 545-558. [CrossRef] [PubMed]

135. Evans, W.E.; Relling, M.V.; Rahman, A.; McLeod, H.L.; Scott, E.P.; Lin, J.S. Genetic basis for a lower prevalence of deficient CYP2D6 oxidative drug metabolism phenotypes in black Americans. J. Clin. Investig. 1993, 91, 2150-2154. [CrossRef] [PubMed]

136. Dahl, M.L.; Yue, Q.Y.; Roh, H.K.; Johansson, I.; Säwe, J.; Sjöqvist, F.; Bertilsson, L. Genetic analysis of the CYP2D locus in relation to debrisoquine hydroxylation capacity in Korean, Japanese and Chinese subjects. Pharmacogenetics 1995, 5, 159-164. [CrossRef] [PubMed]

137. Wang, S.L.; Huang, J.D.; Lai, M.D.; Liu, B.H.; Lai, M.L. Molecular basis of genetic variation in debrisoquin hydroxylation in Chinese subjects: Polymorphism in RFLP and DNA sequence of CYP2D6. Clin. Pharmacol. Ther. 1993, 53, 410-418. [CrossRef] [PubMed]

138. Wu, D.; Otton, S.V.; Sproule, B.A.; Busto, U.; Inaba, T.; Kalow, W.; Sellers, E.M. Inhibition of human cytochrome P450 2D6 (CYP2D6) by methadone. Br. J. Clin. Pharmacol. 1993, 35, 30-34. [CrossRef] [PubMed]

139. Borges, S.; Desta, Z.; Li, L.; Skaar, T.C.; Ward, B.A.; Nguyen, A.; Jin, Y.; Storniolo, A.M.; Nikoloff, D.M.; $\mathrm{Wu}$, L.; et al. Quantitative effect of CYP2D6 genotype and inhibitors on tamoxifen metabolism: Implication for optimization of breast cancer treatment. Clin. Pharmacol. Ther. 2006, 80, 61-74. [CrossRef] [PubMed]

140. Goetz, M.P.; Kamal, A.; Ames, M.M. Tamoxifen pharmacogenomics: The role of CYP2D6 as a predictor of drug response. Clin. Pharmacol. Ther. 2008, 83, 160-166. [CrossRef] [PubMed]

141. Ullrich, V.; Weber, P.; Wollenberg, P. Tetrahydrofurane-An inhibitor for ethanol-induced liver microsomal cytochrome P450. Biochem. Biophys. Res. Commun. 1975, 64, 808-813. [CrossRef]

142. Ohnishi, K.; Lieber, C.S. Reconstitution of the microsomal ethanol-oxidizing system. Qualitative and quantitative changes of cytochrome P-450 after chronic ethanol consumption. J. Biol. Chem. 1977, 252, 7124-7131. [PubMed]

143. Lasker, J.M.; Raucy, J.; Kubota, S.; Bloswick, B.P.; Black, M.; Lieber, C.S. Purification and characterization of human liver cytochrome P-450-ALC. Biochem. Biophys. Res. Commun. 1987, 148, 232-238. [CrossRef]

144. Yang, C.S.; Tu, Y.Y.; Koop, D.R.; Coon, M.J. Metabolism of nitrosamines by purified rabbit liver cytochrome P-450 isozymes. Cancer Res. 1985, 45, 1140-1145. [PubMed]

145. Morgan, E.T.; Koop, D.R.; Coon, M.J. Comparison of six rabbit liver cytochrome P-450 isozymes in formation of a reactive metabolite of acetaminophen. Biochem. Biophys. Res. Commun. 1983, 112, 8-13. [CrossRef]

146. Lieber, C.S. Cytochrome P-4502E1: Its physiological and pathological role. Physiol. Rev. 1997, 77, 517-544. [CrossRef] [PubMed]

147. Tsutsumi, M.; Lasker, J.M.; Shimizu, M.; Rosman, A.S.; Lieber, C.S. The intralobular distribution of ethanol-inducible P450IIE1 in rat and human liver. Hepatology 1989, 10, 437-446. [CrossRef] [PubMed]

148. Koop, D.R.; Chernosky, A.; Brass, E.P. Identification and induction of cytochrome P450 2E1 in rat Kupffer cells. J. Pharmacol. Exp. Ther. 1991, 258, 1072-1076. [PubMed]

149. McCarver, D.G.; Byun, R.; Hines, R.N.; Hichme, M.; Wegenek, W. A genetic polymorphism in the regulatory sequences of human CYP2E1: Association with increased chlorzoxazone hydroxylation in the presence of obesity and ethanol intake. Toxicol. Appl. Pharmacol. 1998, 152, 276-281. [CrossRef] [PubMed]

150. Ueno, Y.; Adachi, J.; Imamichi, H.; Nishimura, A.; Tatsuno, Y. Effect of the cytochrome P-450IIE1 genotype on ethanol elimination rate in alcoholics and control subjects. Alcohol. Clin. Exp. Res. 1996, 20, 17A-21A. [CrossRef] [PubMed]

151. Ueshima, Y.; Tsutsumi, M.; Takase, S.; Matsuda, Y.; Kawahara, H. Acetaminophen metabolism in patients with different cytochrome P-4502E1 genotypes. Alcohol. Clin. Exp. Res. 1996, 20, 25A-28A. [CrossRef] [PubMed]

152. Grove, J.; Brown, A.S.; Daly, A.K.; Bassendine, M.F.; James, O.F.; Day, C.P. The RsaI polymorphism of CYP2E1 and susceptibility to alcoholic liver disease in Caucasians: Effect on age of presentation and dependence on alcohol dehydrogenase genotype. Pharmacogenetics 1998, 8, 335-342. [CrossRef] [PubMed]

153. Lamba, J.K.; Lin, Y.S.; Schuetz, E.G.; Thummel, K.E. Genetic contribution to variable human CYP3A-mediated metabolism. Adv. Drug Deliv. Rev. 2002, 54, 1271-1294. [CrossRef]

154. Hustert, E.; Haberl, M.; Burk, O.; Wolbold, R.; He, Y.Q.; Klein, K.; Nuessler, A.C.; Neuhaus, P.; Klattig, J.; Eiselt, R.; et al. The genetic determinants of the CYP3A5 polymorphism. Pharmacogenetics 2001, 11, 773-779. [CrossRef] [PubMed] 
155. Kuehl, P.; Zhang, J.; Lin, Y.; Lamba, J.; Assem, M.; Schuetz, J.; Watkins, P.B.; Daly, A.; Wrighton, S.A.; Hall, S.D.; et al. Sequence diversity in CYP3A promoters and characterization of the genetic basis of polymorphic CYP3A5 expression. Nat. Genet. 2001, 27, 383-391. [CrossRef] [PubMed]

156. Okubo, M.; Murayama, N.; Shimizu, M.; Shimada, T.; Guengerich, F.P.; Yamazaki, H. CYP3A4 intron 6 C>T polymorphism (CYP3A4*22) is associated with reduced CYP3A4 protein level and function in human liver microsomes. J. Toxicol. Sci. 2013, 38, 349-354. [CrossRef] [PubMed]

157. Elens, L.; Becker, M.L.; Haufroid, V.; Hofman, A.; Visser, L.E.; Uitterlinden, A.G.; Stricker, B.C.H.; van Schaik, R.H. Novel CYP3A4 intron 6 single nucleotide polymorphism is associated with simvastatin-mediated cholesterol reduction in the Rotterdam Study. Pharmacogenet. Genom. 2011, 21, 861-866. [CrossRef] [PubMed]

158. Elens, L.; Bouamar, R.; Hesselink, D.A.; Haufroid, V.; van Gelder, T.; van Schaik, R.H. The new CYP3A4 intron $6 \mathrm{C}>\mathrm{T}$ polymorphism $\left(C Y P 3 A 4^{*} 22\right)$ is associated with an increased risk of delayed graft function and worse renal function in cyclosporine-treated kidney transplant patients. Pharmacogenet. Genom. 2012, 22, 373-380. [CrossRef] [PubMed]

159. Klein, K.; Zanger, U.M. Pharmacogenomics of Cytochrome P450 3A4: Recent Progress toward the "Missing Heritability" Problem. Front. Genet. 2013, 4, 12. [CrossRef] [PubMed]

160. Wang, D.; Sadee, W. CYP3A4 intronic SNP rs35599367 (CYP3A4*22) alters RNA splicing. Pharmacogenet. Genom. 2016, 26, 40-43. [CrossRef] [PubMed]

161. Zhang, H.; Chen, M.; Wang, X.; Yu, S. Patients with $C Y P 3 A 4^{*} 1 G$ genetic polymorphism consumed significantly lower amount of sufentanil in general anesthesia during lung resection. Medicine 2017, 96, e6013. [CrossRef] [PubMed]

162. Zhang, W.; Chang, Y.Z.; Kan, Q.C.; Zhang, L.R.; Li, Z.S.; Lu, H.; Wang, Z.Y.; Chu, Q.J.; Zhang, J. CYP3A4¹G genetic polymorphism influences CYP3A activity and response to fentanyl in Chinese gynecologic patients. Eur. J. Clin. Pharmacol. 2010, 66, 61-66. [CrossRef] [PubMed]

163. Jacqz-Aigrain, E.; Funck-Brentano, C.; Cresteil, T. CYP2D6- and CYP3A-dependent metabolism of dextromethorphan in humans. Pharmacogenetics 1993, 3, 197-204. [CrossRef] [PubMed]

164. McDonald, M.G.; Rieder, M.J.; Nakano, M.; Hsia, C.K.; Rettie, A.E. CYP4F2 is a vitamin K1 oxidase: An explanation for altered warfarin dose in carriers of the V433M variant. Mol. Pharmacol. 2009, 75, 1337-1346. [CrossRef] [PubMed]

165. Danese, E.; Montagnana, M.; Johnson, J.A.; Rettie, A.E.; Zambon, C.F.; Lubitz, S.A.; Suarez-Kurtz, G.; Cavallari, L.H.; Zhao, L.; Huang, M.; et al. Impact of the CYP4F2 p.V433M polymorphism on Coumarin dose requirement: Systematic review and meta-analysis. Clin. Pharmacol. Ther. 2012, 92, 746-756. [CrossRef] [PubMed]

166. Alsmadi, O.; John, S.E.; Thareja, G.; Hebbar, P.; Antony, D.; Behbehani, K.; Thanaraj, T.A. Genome at juncture of early human migration: A systematic analysis of two whole genomes and thirteen exomes from Kuwaiti population subgroup of inferred Saudi Arabian tribe ancestry. PLoS ONE 2014, 9, e99069. [CrossRef] [PubMed]

167. Au, N.T.; Reyes, M.; Boyer, B.B.; Hopkins, S.E.; Black, J.; O’Brien, D.; Fohner, A.E.; Yracheta, J.; Thornton, T.; Austin, M.A.; et al. Dietary and genetic influences on hemostasis in a Yup'ik Alaska Native population. PLoS ONE 2017, 12, e0173616. [CrossRef] [PubMed]

168. Au, N.T.; Ryman, T.; Rettie, A.E.; Hopkins, S.E.; Boyer, B.B.; Black, J.; Philip, J.; Yracheta, J.; Fohner, A.E.; Reyes, M.; et al. Dietary Vitamin K and Association with Hepatic Vitamin K Status in a Yup'ik Study Population from Southwestern Alaska. Mol. Nutr. Food Res. 2017. [CrossRef] [PubMed]

169. Johnson, J.A.; Cavallari, L.H. Warfarin pharmacogenetics. Trends Cardiovasc. Med. 2015, 25, 33-41. [CrossRef] [PubMed]

170. Fullerton, S.M.; Yu, J.H.; Crouch, J.; Fryer-Edwards, K.; Burke, W. Population description and its role in the interpretation of genetic association. Hum. Genet. 2010, 127, 563-572. [CrossRef] [PubMed]

171. Woodahl, E.L.; Lesko, L.J.; Hopkins, S.; Robinson, R.F.; Thummel, K.E.; Burke, W. Pharmacogenetic research in partnership with American Indian and Alaska Native communities. Pharmacogenomics 2014, 15, 1235-1241. [CrossRef] [PubMed] 
172. Shaw, J.L.; Robinson, R.; Starks, H.; Burke, W.; Dillard, D.A. Risk, reward, and the double-edged sword: Perspectives on pharmacogenetic research and clinical testing among Alaska Native people. Am. J. Public Health 2013, 103, 2220-2225. [CrossRef] [PubMed]

173. Morales, C.T.; Muzquiz, L.I.; Howlett, K.; Azure, B.; Bodnar, B.; Finley, V.; Incashola, T.; Mathias, C.; Laukes, C.; Beatty, P.; et al. Partnership with the Confederated Salish and Kootenai Tribes: Establishing an Advisory Committee for Pharmacogenetic Research. Prog. Community Health Partnersh. 2016, 10, 173-183. [CrossRef] [PubMed]

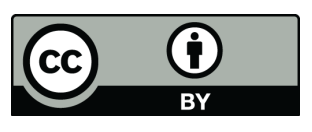

(c) 2018 by the authors. Licensee MDPI, Basel, Switzerland. This article is an open access article distributed under the terms and conditions of the Creative Commons Attribution (CC BY) license (http:/ / creativecommons.org/licenses/by/4.0/). 